\title{
Development of Pillared Clays for Wet Hydrogen Peroxide Oxidation of Phenol and Its Application in the Posttreatment of Coffee Wastewater
}

\author{
Nancy R. Sanabria, Rafael Molina, and Sonia Moreno \\ Estado Sólido y Catálisis Ambiental (ESCA), Departamento de Química, Universidad Nacional de Colombia, \\ Carrera 30 No. 45-03, Bogotá, Colombia \\ Correspondence should be addressed to Sonia Moreno, smorenog@unal.edu.co
}

Received 29 May 2012; Accepted 26 September 2012

Academic Editor: Meenakshisundaram Swaminathan

Copyright ( $) 2012$ Nancy R. Sanabria et al. This is an open access article distributed under the Creative Commons Attribution License, which permits unrestricted use, distribution, and reproduction in any medium, provided the original work is properly cited.

This paper focuses on the use of pillared clays as catalysts for the Fenton-like advanced oxidation, specifically wet hydrogen peroxide catalytic oxidation (WHPCO). This paper discusses the limitations on the application of a homogeneous Fenton system, development of solid catalysts for the oxidation of phenol, advances in the synthesis of pillared clays, and their potential application as catalysts for phenol oxidation. Finally, it analyzes the use of pillared clays as heterogeneous Fenton-like catalysts for a real wastewater treatment, emphasizing the oxidation of phenolic compounds present in coffee wastewater. Typically, the wet hydrogen peroxide catalytic oxidation in a real effluent system is used as pretreatment, prior to biological treatment. In the specific case of coffee wet processing wastewater, catalytic oxidation with pillared bentonite with Al-Fe is performed to supplement the biological treatment, that is, as a posttreatment system. According to the results of catalytic activity of pillared bentonite with Al-Fe for oxidation of coffee processing wastewater ( $56 \%$ phenolic compounds conversion, $40 \%$ selectivity towards $\mathrm{CO}_{2}$, and high stability of active phase), catalytic wet hydrogen peroxide oxidation emerges as a viable alternative for management of this type of effluent.

\section{Introduction}

1.1. Development of Heterogeneous Fenton-Like Catalysts. One of the most effective technologies to remove organic pollutants from aqueous solutions is the Fenton's reagent treatment [1]. Fenton's reagent was developed in the 1890s by Henry John Horstman Fenton and consists of a homogeneous solution of hydrogen peroxide and an iron salt [2]. The mechanism for producing free hydroxyl radicals in Fenton $\left(\mathrm{Fe}^{2+} / \mathrm{H}_{2} \mathrm{O}_{2}\right)$ and Fenton-like processes $\left(\mathrm{Fe}^{3+} / \mathrm{H}_{2} \mathrm{O}_{2}\right)$ is very complex and thought to occur in the following stages [3-7]:

$$
\begin{gathered}
\mathrm{Fe}^{2+}+\mathrm{H}_{2} \mathrm{O}_{2} \longrightarrow \mathrm{Fe}^{3+}+\mathrm{HO}^{-}+\mathrm{HO}^{\bullet} \\
\mathrm{Fe}^{3+}+\mathrm{H}_{2} \mathrm{O}_{2} \longrightarrow \mathrm{Fe}-\mathrm{OOH}^{+2}+\mathrm{H}^{+} \\
\mathrm{Fe}-\mathrm{OOH}^{+2} \longrightarrow \mathrm{Fe}^{2+}+\mathrm{HO}_{2}^{\cdot}
\end{gathered}
$$

$$
\begin{gathered}
\mathrm{Fe}^{2+}+\mathrm{HO}^{\bullet} \longrightarrow \mathrm{Fe}^{3+}+\mathrm{HO}^{-} \\
\mathrm{Fe}^{3+}+\mathrm{H}_{2} \mathrm{O}_{2} \longrightarrow \mathrm{Fe}^{2+}+\mathrm{HO}_{2}^{\bullet}+\mathrm{H}^{+} \\
\mathrm{HO}+\mathrm{H}_{2} \mathrm{O}_{2} \longrightarrow \mathrm{H}_{2} \mathrm{O}+\mathrm{HO}_{2}^{\bullet} \\
2 \mathrm{Fe}^{2+}+\mathrm{H}_{2} \mathrm{O}_{2}+2 \mathrm{H}^{+} \longrightarrow 2 \mathrm{Fe}^{3+}+2 \mathrm{H}_{2} \mathrm{O} \\
\mathrm{Fe}^{3+}+\mathrm{H}_{2} \mathrm{O}_{2} \longrightarrow \mathrm{Fe}^{2+}+\mathrm{HO}_{2}^{\bullet}+\mathrm{H}^{+}
\end{gathered}
$$

The success of Fenton processes for the oxidation of a variety of organic contaminants is attributed to the generation of hydroxyl radicals formed during the catalytic decomposition of hydrogen peroxide in acidic media, according to the above scheme [8-13]. This reaction is propagated by ferrous ion regeneration, which mainly occurs due to the reduction of the ferric species produced by hydrogen peroxide. However, in these reactions, the rate constant of (1) varies between 63 and $76 \mathrm{~L} / \mathrm{mol} \cdot \mathrm{s}$ whereas the rate constant of (5) is in 
the order of $0.01-0.02 \mathrm{~L} / \mathrm{mol} \cdot \mathrm{s}$ [13-15]. This indicates that the consumption of ferrous ions is faster than regeneration. Therefore, during the process, the formation of a large amount of ferric hydroxide sludge occurs, which supposes additional separation $[13,16]$. Both radicals $\mathrm{HO}^{\bullet}$ and $\mathrm{HO}_{2}^{\bullet}$ react indiscriminately with organic matter, being the second less reactive. In a Fenton oxidation, the hydroxyl radical reacts rapidly with most organic compounds by abstraction of carbon bound hydrogen and double bound addition, initiating a sequence of oxidative degradation reaction which may lead to mineralization of $\mathrm{CO}_{2}, \mathrm{H}_{2} \mathrm{O}$, and the production of carboxylic acids [6, 17-19].

Catalytic oxidation reactions are almost exclusively limited to transition elements because these may exist in more than one state of oxidation, making the establishment of a repetitive oxidation-reduction cycle possible [20-22]. Therefore, these reactions also occur with transition metal ions such as $\mathrm{Fe}^{3+}$ or $\mathrm{Cu}^{2+}$ and are known as Fenton-type reactions [23] as follows

$$
\mathrm{M}^{n+}+\mathrm{H}_{2} \mathrm{O}_{2} \longrightarrow \mathrm{M}^{(n+1)+}+\mathrm{HO}^{-}+\mathrm{HO}^{\circ}
$$

The application of a homogeneous Fenton system has as a disadvantage of the separation and reuse of the catalyst (Fe ions in solution). It is also necessary to control the $\mathrm{pH}$ solution so to avoid precipitation of iron hydroxide $(\mathrm{pH}>5)$ [23]. To resolve some of the above drawbacks, a heterogeneous Fenton-like catalyst has been developed, that is, solids containing the cations of transition metals [24, 25]. This way, metals and the selected support directly affect the catalytic activity because they are determinant factors in the stability of the supported metal and its dispersion [26, 27].

A variety of solid catalysts among which are metal oxide ( $\mathrm{CuO}$ and $\left.\mathrm{Cu} / \mathrm{Al}_{2} \mathrm{O}_{3}\right)$ [28], Fe-clay [29], metal oxide impregnated activated carbon $\left(\mathrm{Fe}_{2} \mathrm{MO}_{4}, \mathrm{M}: \mathrm{Fe}\right.$, and $\mathrm{Mn}$ ) [30], iron molybdate $\mathrm{Fe}_{2}\left(\mathrm{MoO}_{4}\right)_{3}$ [31], CuFeZSM-5 zeolite [32], Fe exchanged/supported on zeolite [33-35], goethite [36], $\mathrm{Fe}^{0} / \mathrm{Fe}_{3} \mathrm{O}_{4}$ composites [37, 38], nano magnetite [39], iron containing SBA-15 [40-42], and Al-Fe-pillared clays [43-45] have been evaluated in Fenton reactions. Some degraded organic compounds include dye (reactive blue 4 [29], methyl orange [30], acid orange II [31], rhodamine 6G [32], acid red 14 [33]), p-chlorophenol [28], 2-chlorophenol [36] and phenol [34, 40-42].

1.2. Heterogeneous Fenton-Like Catalysts for Phenol Oxidation. Phenol and its compounds are extremely toxic to the environment. These pollutants are released into the surface water bodies by oil refineries, pulp and paper, pharmaceutical and pesticide industries, and by several other chemical plants [74]. Phenol is toxic even at low concentrations, and its presence in natural waters can also lead to the formation of substituted compounds during disinfection and oxidation processes [75].

Phenol is also relevant in the field of environmental research because it has been chosen frequently as a model pollutant. Much data is available on its removal and destruction, in particular with respect to wastewater treatments [75]. The presence of phenol in the environment is acutely toxic to mankind; hence, treatment of phenolic pollutants is essential before disposal [76].

Widely studied methods for the removal of phenol include biological treatment [77], extraction [78], and wet oxidation [79]. However, advanced oxidation processes (AOPs) such as Fenton, photo-Fenton [80], ozone oxidation [81], and photo-catalytic oxidation [82] are successfully used for the removal of phenol [75]. There is an increasing interest in the use of wet hydrogen peroxide catalytic oxidation (WHPCO) for the disposal of phenolic compounds in water, because this method (in comparison, for example, with wet air oxidation) avoids the use of costly reactors, it can be selective towards the conversion of specific substrates, and it is easy to manage $[69,83]$.

Different solids are used in the wet hydrogen peroxide catalytic oxidation of phenol solutions, among which are pillared clays with Al-Cu $[46,58]$, Al-Fe $[45,46,56]$, and Al-Ce-Fe $[47,51,56]$ Fe-exchanged pillared beidellite [59], polymer-supported metal complexes [84], iron species supported on silica-based mesoporous molecular sieves of the MCM-41 and HMS-types [85], commercial $\mathrm{CuO} /$ alumina [86], $\mathrm{Fe}_{2} \mathrm{O}_{3} / \mathrm{CeO}_{2}$ and $\mathrm{WO}_{3} / \mathrm{CeO}_{2}$ [87], $\mathrm{CuO} / \mathrm{CeO}_{2}$ [88], crystalline hematite particles embedded into a mesostructured SBA-15 matrix [89], Fe/activated carbon [90-93], Cu/ZSM-5 [94], iron-based mesoporous silica [41], CuO/SBA-15 [95], and Cu-Ni-Al hydrotalcite [96]. The effect of temperature, catalyst load, hydrogen peroxide concentration, dosage strategies on phenol mineralization, hydrogen peroxide consumption efficiencies, and catalyst stability were studied $[13,59,86,87]$.

One of the most popular catalysts for the oxidation of phenol with $\mathrm{H}_{2} \mathrm{O}_{2}$ is zeolite Fe-ZSM-5, which has been found to be very active but shows diffusion limitations due to the relatively small sized pores [97]. Transition metals containing mesoporous materials, such as MCM-41 and SBA-15, have been appropriate for the oxidation of phenols due to a larger pore size that is expected to enhance diffusion of reagents in comparison with microporous materials. However, these materials are not stable in the reaction medium and go through destruction of mesoporosity and high leaching of the active phase [75].

In the search for other iron containing heterogeneous Fenton-type catalysts that have a low leaching of the active phase at $\mathrm{pH}$ 3-4, where the phenol oxidation with $\mathrm{H}_{2} \mathrm{O}_{2}$ is maximal [75], a new class of catalysts with a bidimensional open structure called pillared interlayered clays (PILCs) was developed. PILCs result from the intercalation of inorganic polycations into the interlayer space of clays to form rigid cross-linked material of uniform microporosity [98]. Due to a high surface area and permanent porosity, they are very attractive solids for use in catalysis [99]. The use of pillared clays as catalytically active supports for phases (mainly Fe and $\mathrm{Cu}$ ) has the advantage that these transition metals show low leaching into a WHPCO reaction $[46,56,58,60,100]$.

1.3. Developments in the Synthesis of Pillared Clays. Barrer and MacLeod first introduced the concept of transforming a lamellar solid into a porous structure by inserting laterally spaced molecular props between the layers of a smectite 
clay mineral [101]. A pillaring agent is any compound which can be intercalated between adjacent layers of a layered compound, maintaining the spacing between adjacent layers upon removal of the solvent, and inducing an experimentally observable pore structure between the layers [102]. When montmorillonites pillared with hydroxylaluminium oligomer $\left[\mathrm{Al}_{13} \mathrm{O}_{4}(\mathrm{OH})_{24}\left(\mathrm{H}_{2} \mathrm{O}\right)_{12}\right]^{7+}$, are heated in air at $500^{\circ} \mathrm{C}$, the Keggin ions lose their water ligands forming shorter $\mathrm{Al}_{13}$ blocks ( $0.84 \mathrm{~nm}$ in height) that become the structure supporting pillars [103, 104]. Although the pillaring cation is the main $\mathrm{Al}_{13}$, the addition of a second inorganic cation can improve the thermal, adsorptive and catalytic properties of the pillared clays [99].

The classical pillaring method involves two steps: first, the addition of the precursor polymer solution (pillaring agent) into the diluted clay mineral dispersion (intercalation). A second step is the thermal treatment of the intercalated clay mineral [99]. A wide variety of factors can influence the intercalation/pillaring process. This variation makes it difficult to compare the results obtained by different authors, and also good reproducibility becomes hard to achieve. The factors influencing this process include the nature of the raw clay used as parent material, nature of the metallic cations, the hydrolysis conditions (concentration, time, and ageing), intercalation time, temperature of synthesis and, finally, the washing, drying and calcination processes [105].

Variants of the traditional method have been researched in order to decrease the water volume and timing of the synthesis. Thus, it has become possible to decrease the volume of water by the use of concentrated suspensions, both clay and the pillaring agent [106-111]. Also, the time of intercalation of montmorillonite with chlorhydrol has been reduced through the use of ultrasound, having led to the obtaining of Al-PILC with a high thermal stability and textural properties superior to those of clay modified with an exchange time of $24 \mathrm{~h}$. In overall, during the intercalation, treatment with ultrasound $[51,112,113]$ and microwaves $[107,114-116]$ has been proved to be an adequate method for reducing the contact time between clay and the pillaring agent [57].

Although, in the past 30 years, several studies highlighting some applications of industrial pillared clays have been published, such materials have not been used as commercial catalysts primarily due to the difficulty of extending the laboratory synthesis to an industrial scale [57]. However, in 2005, a procedure for pillaring clays with aluminum, which minimizes the processing time and the amount of water used, allowing its extension to an industrial level was developed. To simplify the synthesis of Al-PILC, nonpurified clay and the pillaring agent in a solid state are used, so that clay powder and solid $\mathrm{Al}_{13}$ nitrate are placed together in a dialysis membrane [117].

A diversity of raw clays has been used for the preparation of these pillared materials, around $80 \%$ corresponding to bentonite-montmorillonite [118]. In pursuing the use and valorization of Colombian clay minerals, a series of systematic studies were carried out modifying, via pillaring of bentonite, clays from Valle del Cauca. One of the largest companies in Colombia exploiting and marketing bentonite is located in that Colombian region. The purpose of using such clays was to obtain catalysts (pillared bentonite) for removal of phenolic compounds in an aqueous solution by a heterogeneous Fenton system, in which the iron and/or cerium species were supported on bentonite. Table 1 summarizes results of the research conducted.

The first pillared bentonites with Al-Fe and Al-Ce-Fe were synthesized using the conventional method of diluted pillaring solution and diluted suspension of clay ( $2 \mathrm{wt} \%)$, which involves the use of large volumes of water and long synthesis times. The pillared clays were very efficient catalysts in the reaction of a phenol oxidation in diluted aqueous media under mild experimental conditions $\left(25^{\circ} \mathrm{C}\right.$ and atmospheric pressure), as well as in the elimination of different intermediary compounds of the reaction, reaching highmineralization levels. The catalysts showed high stability in the reaction media due to the strong interaction between the iron species and the catalyst support. The incorporation of cerium showed a favorable effect in pillaring of the materials, allowing the increase of the basal spacing and enhancing the catalytic activity of the catalysts [47-50]. Carriazo et al. performed the characterization of pillaring species of Al-Ce$\mathrm{Fe}$, finding three different crystalline structures (boehmite, $\alpha-\mathrm{Fe}_{2} \mathrm{O}_{3}$, and $\mathrm{CeO}_{2}$ ) into the solid synthesized from the Al-Ce-Fe polyhydroxocationic solution. The EPR analysis confirmed the formation of iron oxide particles and the likely inclusion of isolated $\mathrm{Fe}^{3+}$ species into the alumina matrix [50].

To expand the pillaring process to an industrial scale, it was necessary to simplify procedures and optimization of the unit operations involved, particularly to decrease the volume of water and synthesis times. In this regard, Pérez et al. used ultrasound for aging and intercalating of pillared bentonite with Al-Ce and Al-Ce-Fe. The use of ultrasound showed a clear effect in the synthesis of this type of solids allowing the synthesis in a shorter time and preserving the physicalchemical characteristics as well as catalytic activity in the oxidation reactions [51]. Olaya et al. used microwaves and ultrasound, both in the formation of the polymeric precursor and in the stage of intercalation in concentrated suspensions of clay, finding that this type of radiation improves the formation of pillars and promotes the catalytic activity of the final solid [53-55].

With a procedure similar to that developed by Aouad et al. [117], Sanabria et al. propose a new methodology for the synthesis of clays pillared with mixed Al-Fe and Al-CeFe systems, using minimal volumes of water and reducing intercalation times. This methodology involves the synthesis of the solid polymeric precursor and its use as a pillaring agent. The use of powdered clay and a solid pillaring agent, contained in a dialysis membrane, considerably reduces the amount of water used in the conventional synthesis. The intercalation of the polymeric precursor in clay is favored by the use of ultrasound, reducing long contact times required in conventional synthesis into diluted suspensions $[52,56,57]$. 
TABLE 1: Bentonite-based catalysts for oxidation of phenol using Fenton-like AOPs.

\begin{tabular}{|c|c|c|c|c|}
\hline Pillared bentonite & Year & Synthesis condition & Development & Reference \\
\hline $\begin{array}{l}\mathrm{B}-\mathrm{Fe}[50] \\
\mathrm{B}-\mathrm{Fe}[100]\end{array}$ & 2003 & $\begin{array}{l}\text { Pillaring solution: dilute } \\
\text { Suspension clay: } 2 \mathrm{wt} \% \\
\text { Time intercalation: } 48 \mathrm{~h}\end{array}$ & $\begin{array}{l}\text { This is the first work using natural } \\
\text { bentonite from Valle del Cauca. }\end{array}$ & {$[46]$} \\
\hline $\begin{array}{l}\text { Al-Fe }(10 \%) \\
\text { Al-Ce-Fe (10\%) } \\
\text { Al-Ce-Fe }(5 \%) \\
\text { Al-Ce-Fe }(1 \%)\end{array}$ & $\begin{array}{l}2005 \\
2007\end{array}$ & $\begin{array}{l}\text { Pillaring solution: dilute } \\
\text { Suspension clay: } 2 \mathrm{wt} \% \\
\text { Time intercalation: } 24 \mathrm{~h}\end{array}$ & $\begin{array}{l}\text { Addition of Ce during the synthesis of the } \\
\text { catalysts show favorable results in } \\
\text { phenol oxidation. }\end{array}$ & [47-49] \\
\hline $\mathrm{B}-\mathrm{AlCe}(10) \mathrm{Fe}(10)$ & 2008 & $\begin{array}{l}\text { Pillaring solution: dilute } \\
\text { Suspension clay: } 2 \mathrm{wt} \% \\
\text { Time intercalation: } 24 \mathrm{~h}\end{array}$ & $\begin{array}{l}\text { The clay pillared with the Al-Ce-Fe mixed } \\
\text { solution is a very active and selective } \\
\text { catalyst in the phenol oxidation. }\end{array}$ & {$[50]$} \\
\hline $\begin{array}{l}\text { AlCe24US } \\
\text { AlCeUS24 } \\
\text { AlCeFe24US } \\
\text { AlCeFeUS24 } \\
\text { AlCeFe2424 }\end{array}$ & 2008 & $\begin{array}{l}\text { Pillaring solution: dilute } \\
\text { Aging: } 24 \text { h or } 10 \mathrm{~min} \text { ultrasound } \\
\text { (50 kHz) } \\
\text { Suspension clay: } 2 \mathrm{wt} \% \\
\text { Time intercalation: } 24 \text { h or } 10 \mathrm{~min} \text { US }\end{array}$ & $\begin{array}{l}\text { Ultrasound considerably reduces the } \\
\text { modification time of the pillared clays. } \\
\text { The catalysts show physical-chemical and } \\
\text { catalytic properties similar to those when } \\
\text { synthesizing by the conventional method. }\end{array}$ & {$[51]$} \\
\hline $\begin{array}{l}\text { B1-AlFe } \\
\text { B2-AlFe } \\
\text { B3-AlFe }\end{array}$ & 2008 & $\begin{array}{l}\text { Pillaring agent: solid } \\
\text { Clay: powder } \\
\text { Intercalation: dialysis membrane } \\
\text { Time intercalation: } 60 \mathrm{~h}\end{array}$ & $\begin{array}{l}\text { Using powdered clay and a solid pillaring } \\
\text { agent, the water volume needed in the } \\
\text { synthesis of pillared clays was reduced. }\end{array}$ & {$[52]$} \\
\hline $\begin{array}{l}\mathrm{AlCe}(10 \%) \\
\mathrm{MAl}-\mathrm{Fe} \\
\text { UAl-Fe } \\
\mathrm{AlCeFe}(10 \%) \\
\mathrm{MAl}-\mathrm{Fe}-\mathrm{Ce} \\
\text { UAl-Fe-Ce }\end{array}$ & 2009 & $\begin{array}{l}\text { Pillaring agent: solid } \\
\text { Aging and intercalation: microwaves } \\
(160 \mathrm{~W}, 10 \mathrm{~min}) \text { or ultrasound }(50 \mathrm{kHz} \text {, } \\
30 \mathrm{~min}) \\
\text { Clay: powder } \\
\text { Intercalation: dialysis membrane }\end{array}$ & $\begin{array}{l}\text { The use of microwaves and ultrasound } \\
\text { significantly reduces the synthesis time of } \\
\text { pillared clays. }\end{array}$ & {$[53]$} \\
\hline
\end{tabular}

$\operatorname{MAlFe}(1)$,

$\operatorname{MAlFe}(10)$

$\mathrm{UAlFe}(1)$

$\operatorname{UAlFe}(10)$

MAlCeFe(1-1)

2009

$\operatorname{MAlCeFe}(5-1)$

MAlCeFe(10-10)

$\mathrm{UAlCeFe}(1-1)$

$\mathrm{UAlCeFe}(5-1)$

UAlCeFe(10-10)

\begin{tabular}{|c|c|c|}
\hline B2R, BT21 & & Pillaring solution: dilute \\
\hline B21, B22 & 2009 & $\begin{array}{l}\text { Aging and intercalation: microwaves } \\
(160 \mathrm{~W}, 10 \mathrm{~min})\end{array}$ \\
\hline B301, B302 & & $\mathrm{OH} / \mathrm{metal}: 2.0$ \\
\hline $\mathrm{BD} 1, \mathrm{BD} 2$ & & Suspension clay: $2 \%, 3 \%$, and $100 \%$ \\
\hline
\end{tabular}

B-Al US

$\mathrm{B}-\mathrm{AlFe}(2) \mathrm{US}$

$\mathrm{B}-\mathrm{AlFe}(5) \mathrm{US}$

2009

$\mathrm{B}-\mathrm{AlFe}(10) \mathrm{US}$

B-AlFe

\section{Pillaring agent: Solid}

Clay: powder

Intercalation: dialysis membrane

Time intercalation: $30 \mathrm{~min}$ (ultrasound,

$50 \mathrm{kHz}$ )
The use of microwaves and ultrasound significantly reduces the synthesis time of pillared clays.
Clay: powder
The use of microwaves significantly reduces the synthesis time. Additionally, the use of a clay suspension (30\%) and dry clay reduces the amount of water used in the synthesis.
With the methodology here used, the volume of water needed and the synthesis time of pillared clays were reduced. 
The synthesis of pillared clays by mixed systems Al-Fe and $\mathrm{Al}-\mathrm{Ce}-\mathrm{Fe}$ in a concentrated medium allows a $90 \%-$ $95 \%$ decrease in the volume of water and a reduction in the intercalation times between $70 \%$ and $93 \%$ with respect to the conventional synthesis. The pillared clays using this new methodology show a catalytic activity and selectivity comparable to those of solids synthesized by the conventional method in a dilute medium $[56,119]$. An important aspect is that the $\mathrm{Fe}$ introduced into the clays is preferentially associated with the alumina pillars and not with surface $\mathrm{Fe}$ oxides (cluster). This is explained by the high stability of the active phase in the reaction medium [57].

The commercial use of PILCs based catalysts not only depends on the optimization of the synthesis, but also on the ability to shape the powder material into pellets, agglomerates, and so forth. These materials should keep their chemical properties, reactivity, and stability in the reaction medium. The manufacture of pellets, Raschig rings and monoliths, that involve pillared montmorillonites has basically been accomplished by the use of extrusion techniques [120].

With the developments in the synthesis of pillared clays in a concentrated medium, the manufacture of extruded materials with $\mathrm{Al}-\mathrm{Fe} \mathrm{Al}-\mathrm{Ce}-\mathrm{Fe}$ pillared bentonites was achieved. We found that the most adequate composition of the mixture of poly(hydroxo metal) bentonite/binder/water for the manufacture of extrudates with B-AlFe and B-AlCeFe was $42 / 28 / 30$. The use of poly(hydroxo metal) bentonite (dried at $60^{\circ} \mathrm{C}$ ) and not the pillared bentonite (after calcination at $400^{\circ} \mathrm{C}$ ) considerably improved the mechanical stability of the extrudates. The mechanical resistance of B$\mathrm{AlFe}$ and B-AlCeFe based extrudates depended on the calcination temperature. At $500^{\circ} \mathrm{C}$, good mechanical strength and sufficient stability to immersion in water were achieved. The extrudates largely preserved the structural and textural properties of $\mathrm{Al}-\mathrm{Fe}$ and $\mathrm{Al}-\mathrm{Ce}-\mathrm{Fe}-\mathrm{PILC}$ and retained the catalytic properties of powdered pillared clays $[27,61]$.

\subsection{Wet Hydrogen Peroxide Catalytic Oxidation (WHCPO)} of Phenol Using Pillared Clay. Advanced oxidation processes (AOPs) are based on physical and chemical processes capable of fundamental changes in the chemical structure of contaminants, as they involve the generation and use of transitory species with a high oxidation power, mainly the hydroxyl radical $\left(\mathrm{OH}^{*}\right)$ [6]. Among advanced oxidation processes, the activation of hydrogen peroxide by means of a solid catalyst (wet hydrogen peroxide catalytic oxidation, WHPCO) has turned out to be the most promising process for the oxidation of phenol and phenol-like compounds and application in the treatment of wastewater $[23,83,118]$.

Oxidation processes using hydrogen peroxide as oxidant have turned out to be a viable alternative for the wastewater treatments of medium-high total organic carbon concentrations. Furthermore, iron is an abundant and nontoxic element; hydrogen peroxide does not give origin to any harmful by-products and it is a nontoxic and ecological reactant $[6,121]$.

Among the different materials used as support for oxidation reaction in a liquid phase, pillared clays represent around 7\% in the existing literature. However, the interest for pillared clays has increased substantially in the last decade, given their use in different oxidation processes such as WHPCO and photocatalytic oxidation [118]. The properties of pillared clays-based catalysts have been mainly studied in the wet hydrogen peroxide oxidation of phenolic compounds as model molecules, among them are phenol $[44,45,48,57$, $58,62,65,68], 4$-nitrophenol [122, 123], tyrosol [70], and p-coumaric and p-hydroxybenzoic acids [69].

Pillared clays with $\mathrm{Al}-\mathrm{Fe}$ and $\mathrm{Al}-\mathrm{Cu}$ are promissory catalysts for wet hydrogen peroxide oxidation of phenol, because they combine a porous support and active sites for the adsorption of organic compounds in the activation of $\mathrm{H}_{2} \mathrm{O}_{2}$ [68]. The use of pillared clays with copper in a Fenton reaction would be important since the optimal $\mathrm{pH}$ of that reaction is close to 6, while for AlFe-PILC, the optimum $\mathrm{pH}$ ranges between 3.5 and $4.0[46,62,100]$. The properties of AlCu-PILC were compared with those of analogous iron-based clays (AlFe-PILC) in the wet hydrogen peroxide catalytic oxidation of model phenolic compounds. These two catalysts have comparable performances in all these reactions, although they showed some differences in the rates of the various steps of the reaction. In particular, $\mathrm{AlCu}-\mathrm{PILC}$ showed a lower formation of oxalic acid (main intermediate reaction) with respect to Fe-PILC [69]. Among the metals studied as active phase in oxidation processes with pillared clays-supported catalysts, iron is the most frequently used metal, followed by titanium, copper, and chromium [118]; hence, some of the most studied are the pillared clays with Al-Fe.

In general, pillared clays with $\mathrm{Al}-\mathrm{Fe}$ are efficient in phenol elimination under mild experimental conditions (atmospheric pressure and room temperature) without considerable leaching of metal ions $[44,46,56,60]$. AlFePILC achieved high conversions of phenol and TOC thus showing to be very selective towards the formation of $\mathrm{CO}_{2}$, as shown in Table 2.

Cerium (Ce) was introduced into pillared clays with $\mathrm{Al}$ and $\mathrm{Al}-\mathrm{Fe}$, improving the metallic dispersion properties, increasing the pillars resistance [124-126], and favoring the redox properties of the active metallic phase $[48,127]$. The catalysts obtained by the pillaring of Colombian bentonite with $\mathrm{Al}-\mathrm{Fe}$ or $\mathrm{Al}-\mathrm{Ce}-\mathrm{Fe}$ are highly efficient for the reaction of phenol oxidation in diluted aqueous media in moderate conditions of temperature and pressure $\left(25^{\circ} \mathrm{C}\right.$ and atmospheric pressure). The low iron leaching indicate that the active phase of these catalysts is strongly fixed to the clay support and pillars, and that it is highly stable under oxidizing conditions of the reaction medium $[47,48]$.

Most research on the use of pillared clays for the oxidation of phenol was conducted with the powdered catalyst and a few with pellets of Al-Fe pillared clay [27, 61, 66-68]. Therefore, the development of catalysts based on pillared clays not only depends on the optimization of the synthesis, but also on the ability to shape the powder material into structured shapes (e.g., pellets, Raschig rings, and monoliths) that retain the chemical properties and reactivity of the active phase and can be used in fixed bed reactors [27]. 
TABLE 2: Some examples of pillared clays-based catalysts for wet hydrogen peroxide oxidation of phenol.

\begin{tabular}{|c|c|c|c|}
\hline Clay catalyst & Operation conditions & Best performances reached & Reference \\
\hline Fe-Al pillared clays & $\begin{array}{l}T=28^{\circ} \mathrm{C} \\
\text { Phenol } 200 \mathrm{~mL}, 13-38 \mathrm{mg} / \mathrm{L} \\
\text { Catalyst }=0.1-0.7 \mathrm{~g}, \mathrm{pH}=4.0, \text { time }=1-3 \mathrm{~h}\end{array}$ & $\begin{array}{l}X_{\text {phenol }}=100 \% \\
\text { Fe leaching }<0.5 \mathrm{ppm}\end{array}$ & {$[44]$} \\
\hline $\begin{array}{l}(\mathrm{Al}-\mathrm{Cu}) \text {-pillared } \\
\text { clays }\end{array}$ & $\begin{array}{l}T=20^{\circ} \mathrm{C} \\
\text { Phenol } 100 \mathrm{~mL}, 5 \times 10^{-5} \mathrm{M} \\
\text { Catalyst }=0.5 \mathrm{~g}, \mathrm{pH}=4.0-5.0, \text { time }=18 \mathrm{~h}\end{array}$ & $X_{\mathrm{TOC}}=20 \%-60 \%$ & {$[58]$} \\
\hline B-AlFe & $\begin{array}{l}T=25^{\circ} \mathrm{C} \\
\text { Phenol } 100 \mathrm{~mL}, 5 \times 10^{-4} \mathrm{M} \\
\text { Catalyst }=0.5 \mathrm{~g}, \mathrm{pH}=3.7\end{array}$ & $\begin{array}{l}X_{\text {phenol }}=100 \% \\
X_{\text {TOC }}=48 \% \\
\text { Fe leaching }<0.2 \mathrm{ppm} \\
\end{array}$ & {$[56]$} \\
\hline $\mathrm{B}-\mathrm{AlCeFe}$ & As above & $\begin{array}{l}X_{\text {phenol }}=100 \% \\
X_{\text {TOC }}=58 \% \\
\text { Fe leaching }<0.2 \mathrm{ppm}\end{array}$ & {$[56]$} \\
\hline $\begin{array}{l}\text { AlCe24US } \\
\text { AlCeUS24 } \\
\end{array}$ & As above & $\begin{array}{l}X_{\text {phenol }}=100 \% \\
X_{\text {TOC }}=42 \%\end{array}$ & {$[51]$} \\
\hline $\begin{array}{l}\text { AlCeFe24US } \\
\text { AlCeFeUS24 } \\
\text { AlCeFe2424 }\end{array}$ & As above & $\begin{array}{l}X_{\text {phenol }}=100 \% \\
X_{\text {TOC }}=50 \%\end{array}$ & {$[51]$} \\
\hline Fe/Al-PILC & $\begin{array}{l}T=50^{\circ} \mathrm{C} \\
\text { Phenol } 100 \mathrm{~mL}, 250 \mathrm{mg} / \mathrm{L} \\
\text { Catalyst }=0.05-0.1 \mathrm{~g}, \mathrm{pH}=5.0-5.5, \text { time }=3 \mathrm{~h}\end{array}$ & $\begin{array}{l}X_{\text {phenol }}=89 \%-100 \% \\
X_{\mathrm{COD}}=65 \%-89 \% \\
\text { Fe leaching }<2.0 \mathrm{ppm}\end{array}$ & {$[59]$} \\
\hline $\begin{array}{l}\text { B-Fe }[50] \\
\text { B-Fe[100] }\end{array}$ & $\begin{array}{l}T=20^{\circ} \mathrm{C} \\
\text { Phenol } 100 \mathrm{~mL}, 5 \times 10^{-4} \mathrm{M} \\
\text { Catalyst }=0.5 \mathrm{~g}, \mathrm{H}_{2} \mathrm{O}_{2} \text { excess, time }=4 \mathrm{~h}\end{array}$ & $\begin{array}{l}X_{\text {phenol }}=96 \%-100 \% \\
X_{\text {TOC }}=45 \%-70 \% \\
\text { Fe leaching }<0.6 \mathrm{ppm}\end{array}$ & {$[46]$} \\
\hline $\mathrm{B}-\mathrm{Cu}[10]$ & $\begin{array}{l}\text { As above } \\
\mathrm{pH}=5.0-5.5\end{array}$ & $\begin{array}{l}X_{\text {phenol }}=37 \%-70 \% \\
X_{\text {TOC }}=96 \%-100 \% \\
\text { Cu leaching }<0.4 \mathrm{ppm}\end{array}$ & {$[46]$} \\
\hline $\begin{array}{l}(\mathrm{Al}-\mathrm{Fe}) \text {-pillared } \\
\text { clays } \\
\text { (FAZA) }\end{array}$ & $\begin{array}{l}T=25,40 \text {, and } 70^{\circ} \mathrm{C} \\
\text { Phenol } 100 \mathrm{~mL}, 5 \times 10^{-4} \mathrm{M} \\
\text { Catalyst }=0.5-1.0 \mathrm{~g}, \mathrm{pH}=3.5-4.0, \text { time }=0.5-4.0 \mathrm{~h}\end{array}$ & $\begin{array}{l}X_{\text {phenol }}=100 \% \\
X_{\text {TOC }}=63 \%-78 \% \\
\text { Fe leaching } 0.4-0.8 \mathrm{ppm}\end{array}$ & {$[60]$} \\
\hline B-AlFe extruded & $\begin{array}{l}T=25^{\circ} \mathrm{C} \\
\text { Phenol } 250 \mathrm{~mL}, 5 \times 10^{-4} \mathrm{M} \\
\text { Catalyst }=2.08 \mathrm{~g}, \mathrm{pH}=3.7, \text { time }=8-9 \mathrm{~h}\end{array}$ & $\begin{array}{l}X_{\text {phenol }}=100 \% \\
X_{\text {TOC }}=36-50 \% \\
\text { Fe leaching }<0.2 \mathrm{ppm}\end{array}$ & {$[27,61]$} \\
\hline B-AlCeFe extruded & As above & $\begin{array}{l}X_{\text {phenol }}=100 \% \\
X_{\text {TOC }}=42 \%-55 \% \\
\text { Fe leaching }<0.2 \mathrm{ppm} \\
\end{array}$ & {$[27,61]$} \\
\hline FAZA (Al-Fe) & $\begin{array}{l}T=25-70^{\circ} \mathrm{C} \\
\text { Phenol } 100 \mathrm{~mL}, 5 \times 10^{-4} \mathrm{M} \\
\text { Catalyst }=0.1-1.0 \mathrm{~g}, \mathrm{pH}=3.5-3.7, \text { time }=1.0-4.0 \mathrm{~h}\end{array}$ & $\begin{array}{l}X_{\text {phenol }}=83 \%-100 \% \\
X_{\text {TOC }}=21 \%-78 \% \\
\text { Fe leaching } 0.1-0.8 \mathrm{ppm}\end{array}$ & {$[62]$} \\
\hline Al-Fe $(10 \%)$ & $\begin{array}{l}T=25^{\circ} \mathrm{C} \\
\text { Phenol } 100 \mathrm{~mL}, 5 \times 10^{-4} \mathrm{M} \\
\text { Catalyst }=0.5 \mathrm{~g}, \mathrm{pH}=3.7, \text { time }=4 \mathrm{~h}\end{array}$ & $\begin{array}{l}X_{\text {phenol }}=100 \% \\
X_{\text {TOC }}=50 \% \\
\text { Fe leaching } 0.21 \mathrm{ppm}\end{array}$ & {$[47,48]$} \\
\hline $\begin{array}{l}\text { Al-Ce-Fe }(10 \%) \\
\text { Al-Ce-Fe }(5 \%) \\
\text { Al-Ce-Fe }(1 \%)\end{array}$ & As above & $\begin{array}{l}X_{\text {phenol }}=100 \% \\
X_{\text {TOC }}=52 \%-55 \% \\
\text { Fe leaching } 0.25-0.34 \mathrm{ppm}\end{array}$ & {$[47,48]$} \\
\hline $\begin{array}{l}\text { FAZA-1 } \\
\text { FAZA-2 }\end{array}$ & $\begin{array}{l}T=18-70^{\circ} \mathrm{C} \\
\text { Phenol } 100 \mathrm{~mL}, 5 \times 10^{-4} \mathrm{M} \\
\text { Catalyst }=0.5-1.0 \mathrm{~g}, \mathrm{pH}=3.7, \text { time }=4 \mathrm{~h}\end{array}$ & $\begin{array}{l}X_{\text {phenol }}=100 \% \\
X_{\text {TOC }}=51 \%-80 \% \\
\text { Fe leaching }<0.6 \mathrm{ppm}\end{array}$ & {$[63]$} \\
\hline $\mathrm{Al} / \mathrm{Fe}-\mathrm{PILC}$ & $\begin{array}{l}T=25^{\circ} \mathrm{C} \\
\text { Phenol } 125 \mathrm{~mL}, 2000 \mathrm{mg} / \mathrm{L} \\
\mathrm{pH}=3.0-3.5, \text { Time }=6 \mathrm{~h}\end{array}$ & $\begin{array}{l}X_{\text {phenol }}=100 \% \\
X_{\text {TOC }}=65 \% \\
\text { Fe leaching }<2.0 \mathrm{ppm}\end{array}$ & {$[45]$} \\
\hline
\end{tabular}


TABle 2: Continued.

\begin{tabular}{|c|c|c|c|}
\hline Clay catalyst & Operation conditions & Best performances reached & Reference \\
\hline $\begin{array}{l}\operatorname{MAlFe}(1) \\
\operatorname{MAlFe}(10) \\
\operatorname{UAlFe}(1) \\
\operatorname{UAlFe}(10)\end{array}$ & $\begin{array}{l}T=25^{\circ} \mathrm{C} \\
\text { Phenol } 100 \mathrm{~mL}, 5 \times 10^{-4} \mathrm{M} \\
\text { Catalyst }=0.5 \mathrm{~g}, \mathrm{pH}=3.7, \text { time }=4 \mathrm{~h}\end{array}$ & $\begin{array}{l}X_{\text {phenol }}=100 \% \\
X_{\text {TOC }}=54 \%-60 \%\end{array}$ & {$[53,54]$} \\
\hline $\begin{array}{l}\operatorname{MAlCeFe}(1-1) \\
\operatorname{MAlCeFe}(5-1) \\
\operatorname{MAlCeFe}(10-10) \\
\operatorname{UAlCeFe}(1-1) \\
\operatorname{UAlCeFe}(5-1) \\
\mathrm{UAlCeFe}(10-10)\end{array}$ & As above & $\begin{array}{l}X_{\text {phenol }}=100 \% \\
X_{\text {TOC }}=50 \%-57 \%\end{array}$ & {$[53,54]$} \\
\hline $\begin{array}{l}\text { B1-AlFe } \\
\text { B2-AlFe } \\
\text { B3-AlFe }\end{array}$ & As Above & $\begin{array}{l}X_{\text {phenol }}=100 \% \\
X_{\text {TOC }}=49 \%-52 \% \\
\text { Fe leaching }<0.4 \mathrm{ppm}\end{array}$ & {$[52]$} \\
\hline $\begin{array}{l}\mathrm{Fe}_{0.8} \mathrm{Al}_{12.2} \text {-PILC } \\
\mathrm{Fe}_{6.5} \mathrm{Al}_{6.5} \text {-PILC }\end{array}$ & $\begin{array}{l}T=30-60^{\circ} \mathrm{C} \\
\text { Phenol: } \mathrm{H}_{2} \mathrm{O}_{2}=1: 14 \mathrm{~mol} / \mathrm{mol} \\
(20 \mathrm{ml}, 30 \mathrm{wt} \% \text { in water }) \\
\text { Catalyst }=0.25-1.5 \mathrm{~g}, \text { time }=1-7 \mathrm{~h}\end{array}$ & $\begin{array}{l}X_{\text {phenol }}=50 \%-100 \% \\
\text { Fe leaching }< \\
0.01 w t \%-20 w t \%\end{array}$ & {$[64]$} \\
\hline Al-Fe-PILC & $\begin{array}{l}T=25^{\circ} \mathrm{C} \\
5-50 \mathrm{mg} \text { phenol } / \mathrm{L} \mathrm{H}_{2} \mathrm{O} \\
\text { Catalyst }=0.25-1.5 \mathrm{~g}, \mathrm{pH}=3.5-4.0, \text { time }=1-4 \mathrm{~h}\end{array}$ & $X_{\text {phenol }}=38 \%-100 \%$ & {$[65]$} \\
\hline $\begin{array}{l}\text { Extrudates Al-Fe } \\
\text { pillared clay }\end{array}$ & $\begin{array}{l}T=25-90^{\circ} \mathrm{C} \\
100-2000 \mathrm{mg} \text { phenol } / \mathrm{L} \mathrm{H}_{2} \mathrm{O} \\
\text { Catalyst }=0.0-10 \mathrm{~g}, \mathrm{pH}=3.8-6.0, \text { time }=1-4 \mathrm{~h}\end{array}$ & $\begin{array}{l}X_{\text {phenol }}=100 \% \\
X_{\text {TOC }}=35 \%-55 \% \\
\text { Fe leaching }<0.4 \mathrm{ppm}\end{array}$ & {$[66]$} \\
\hline $\begin{array}{l}\text { FAZA powder } \\
\text { FAZA extrudates }\end{array}$ & $\begin{array}{l}T=20^{\circ} \mathrm{C} \\
\text { Ultrasound assisted } \\
\text { Phenol } 100 \mathrm{~mL}, 5 \times 10^{-4} \mathrm{M} \\
\text { Catalyst }=0.5 \mathrm{~g}, \mathrm{pH}=3.5-4.0, \text { time }=4 \mathrm{~h}\end{array}$ & $X_{\text {phenol }}=100 \%$ & {$[67]$} \\
\hline FAZA & $\begin{array}{l}T=25^{\circ} \mathrm{C} \\
\text { Phenol } 100 \mathrm{~mL}, 5 \times 10^{-4} \mathrm{M} \\
\text { Catalyst }=0.5-1.0 \mathrm{~g}, \mathrm{pH}=3.7, \text { time }=4 \mathrm{~h}\end{array}$ & $\begin{array}{l}X_{\text {phenol }}=100 \% \\
X_{\text {TOC }}=65 \% \\
\text { Fe leaching }<0.2 \mathrm{ppm}\end{array}$ & {$[68]$} \\
\hline
\end{tabular}

Extrudates of an Al-Fe pillared clay catalyst suitable for packed-bed operations are evaluated for oxidation of phenol using hydrogen peroxide as the oxidant. The reaction was processed in a semibatch basket reactor under rather mild conditions. Operational parameters were studied under the following conditions: temperature from 25 to $90^{\circ} \mathrm{C}$, atmospheric pressure, initial phenol concentration from 100 to $2000 \mathrm{ppm}$ of the liquid phase, catalyst loading from 0 to $10 \mathrm{~g} / \mathrm{L}$, and input $\mathrm{H}_{2} \mathrm{O}_{2}$ concentration from 0.15 to $0.6 \mathrm{~mol} / \mathrm{L}$. Under these conditions, the Al-Fe pillared clay catalyst achieves a total elimination of phenol and significant total organic carbon (TOC) removal. This catalyst can be used several times without any change in its catalytic properties, and, hence, it would be a promising catalyst for industrial wastewater treatment [66].

Extrudates manufactured with pillared bentonites were also employed in phenol oxidation at $25^{\circ} \mathrm{C}$ and atmospheric pressure. Extrudates with $\mathrm{B}-\mathrm{AlFe}$ and $\mathrm{B}-\mathrm{AlCeFe}$ reached $100 \%$ conversion of phenol and TOC conversion between $30 \%$ and $62 \%$, after $9 \mathrm{~h}$ of reaction. Once the reaction was completed $(9 \mathrm{~h})$, the catalyst was removed and the leachate was recovered and analyzed, showing Fe values in the range of 0.11-0.14 ppm. The outstanding differences in time for the phenol conversion and TOC of extruded materials compared to the powdered materials were a consequence of the agglomeration process and the inherent diffusional limitations [61]. The extruded catalyst retained its catalytic activity during at least 10 consecutive tests $(80 \mathrm{~h})$, and only a loss of mechanical stability was observed for the series containing $\mathrm{B}-\mathrm{AlFe}$ as the active phase. This result proved the importance of cerium in the synthesis of pillared clays with mixed systems because it not only increased the catalytic activity due to its oxygen storage capacity, but also increased the mechanical stability of extruded catalysts in the reaction medium [27].

\section{Fenton Oxidation with Pillared Clays for Wastewater Treatment}

The interest for pillared clays has dramatically increased in the last years, in great part due to their potential applications as catalysts. Metals incorporated in the pillared clay structure are crucial and make them suitable for a number of different 
applications, most of them belonging to the so-called "green chemistry" [118]. This way, pillared clays have been tested as catalysts in different oxidation processes. Distribution of the pollutants studied in the literature corresponds mainly to phenol (22\%), orange II and other dyes (23\%), and only $5 \%$ to industrial effluents [118].

Table 3 summarizes the research related to the use of pillared clays in wet hydrogen peroxide catalytic oxidation (WHPCO) of industry wastewater. The studies have basically focused on real olive oil milling wastewater (OMW). The reason for studying an olive oil mill wastewater effluent is because it constitutes a critical environmental problem in the Mediterranean area that accounts for $95 \%$ of the world olive oil production [128] and generates 30 million $\mathrm{m}^{3}$ of OMW every year [129].

Most treatment studies of OMW are focused on aerobic biodegradation or anaerobic digestion of that material [130]. Unfortunately, due to the effluents' high toxicity and biodegradability, no satisfactory results were obtained by these treatments. Indeed, in order to remove the organic compounds and reduce the methanogenic bacteria inhibition of the OMW, the WHPCO as pretreatment has been researched $[83,131]$.

Tyrosol, p-coumaric, and p-hydroxybenzoic acids have also deserved the attention of some researchers because they are representative compounds of the polyphenolic fraction typically found in olive processing wastewater [69, 70]. The polyphenolic compounds conversion in OMW using Cu-PILC and Fe-PILC is about $45 \%$ and similar for the two catalysts. Therefore, the rate of polyphenolic conversion is around two to three times higher than the rate of TOC abatement, indicating a preferential reduction of these toxic compounds with respect to TOC abatement, in agreement with the goal of toxicity reduction, to improve biodegradability and to minimize as much as possible TOC reduction, because the OMW after WHPCO should go through a biological treatment [69].

\section{Environmental Problems Associated with Coffee Wet Processing in Colombia}

Coffee is one of the largest agricultural-based products sold in international markets and has become the second best-marketed product worldwide, surpassed only by oil [132]. Colombian coffee has become a benchmark for the rest of the world due to the country unique weather and topography, wet processing, and programs to guarantee the coffee's origin. Colombia, the largest producer of washed Arabica coffee worldwide, counts an estimated average coffee production rate of 11 million bags per year ( 1 bag equals $60 \mathrm{~kg}$ of dried coffee beans), with coffee grown by a total of 553,000 families covering an area of 914,000 hectares [133].

The coffee fruit consists of a coloured exocarp (skin), a fleshy, yellowish-white mesocarp (pulp), mucilage layers (covering the two beans) and two coats (the first, a thin, fibrous parchment and the second, a fine membrane, silver skin) [134]. Primary coffee processing refers to the processing of the coffee fruit to obtain coffee beans (also called green coffee beans at this stage). Coffee beans are extracted using one of three different methods: dry processing, wet processing, or semidry processing [135]. Although all methods aim at removing the fruit flesh of the coffee cherry, each method removes the flesh in different ways [136]. In the wet method process, which requires the use of specific equipment and substantial amounts of water, the pulp is eliminated using a pulper, followed by the mucilage's removal by natural fermentation. When fermentation is complete, the wet processed seeds are washed and dried, and the final product is "washed" or "parchment" coffee. Coffee processed using the wet method typically increases the market value of the beans because of its ability to add a soft acidity, good body, and better flavour $[135,136]$.

The mucilage, a by-product of coffee wet processing, is primarily composed by pectin, sugars, water [136, 137], and minor compounds such as tannins, caffeine, and phenols [138]. It is estimated that for every $1 \times 10^{6}$ parchment bags, approximately $55.5 \times 10^{6} \mathrm{~kg}$ of fresh mucilage is generated, resulting in highly polluted nearby tributary water sources where the waste is discharged [139]. For this reason, the National Coffee Research Center-Cenicafé has developed modular anaerobic treatment systems (SMTA, the Spanish acronym) using hydrolytic acidogenic and methanogenic reactors to treat coffee processing wastewater prior to its release, reducing the chemical oxygen demand (COD) by approximately $87 \%$. The remaining $13 \%$ of the COD in the effluent is nondegrading and corresponds to recalcitrant compounds, including phenolic compounds [140]. Treatment of coffee wastewater in a UASB (upflow anaerobic sludge blanket) reactor showed similar results: between $14 \%$ and $44 \%$ of phenolic compounds were removed during anaerobic digestion and, on average, $8 \%$ of the COD remained in the effluent and was not degraded [138]. Because the SMTA effluent still poses toxic consequences for aquatic life, the effluent must go through posttreatment before being discharged into any water source.

To determine the biological impact generated by coffee wet processing wastewater, the National Coffee Research Center of Colombia-Cenicafé conducted bioassays using Chlorella vulgaris (algae), Daphnia pulex (microcrustacean), and Lebistes reticulatus (fish). It was found that the effluent from coffee wastewater can be toxic to the ecosystem at concentrations above $300 \mathrm{ppm}$ of COD, inflicting a $50 \%$ mortality of fish, $43 \%$ of microcrustaceans, and $40 \%$ of algae, a negative impact on the aquatic ecosystem [141].

To complement the biological treatment, an integrated biosystem that uses macrophytes for posttreatment for coffee wet processing wastewater has been proposed, in order to generate the least negative impact on the coffee aquatic ecosystem [139]. However, the biomass produced in these aquatic systems should be properly utilized in other processes such as the production of fertilizers, animal feed, and mushroom growing.

Considering that coffee wastewater is highly biodegradable, biological treatments have been widely used [142-144]. In Colombia, a posttreatment for coffee wastewater is usually not performed because the elimination of $80 \%$ of the initial 
TABLE 3: Some examples of WPHCO of water pollutants (model molecules) or real effluents, using a Fenton reaction catalyzed by pillared clays.

\begin{tabular}{|c|c|c|c|}
\hline Clay catalyst & Organic pollutant & Performances reached & Reference \\
\hline Al/Fe-PILC & $\begin{array}{l}\text { Treatment of municipal leachate from } \\
\text { landfill by catalytic wet peroxide } \\
\text { oxidation using an Al/Fe-pillared } \\
\text { montmorillonite }\end{array}$ & $\begin{array}{l}T=18 \pm 2^{\circ} \mathrm{C} \\
X_{\mathrm{COD}}=50 \% \\
\text { This advanced oxidation process has } \\
\text { enhanced the biodegradability index of the leachate } \\
\text { from } 0.135 \text { to } 0.321 \text { in } 4 \mathrm{~h}\end{array}$ & {$[43]$} \\
\hline $\begin{array}{l}\text { Cu-PILC } \\
\text { Fe-PILC }\end{array}$ & $\begin{array}{l}\text { Phenolic compounds (p-coumaric and } \\
\text { p-hydroxybenzoic acids) and real olive oil } \\
\text { milling wastewater (OMW) }\end{array}$ & $\begin{array}{l}T=70^{\circ} \mathrm{C} \\
X_{\mathrm{p}-\text { coumaric acid }}=100 \% \\
X_{\mathrm{p} \text {-hydroxybenzoic acid }}=100 \%, X_{\mathrm{TOC}}: 74-80 \% \\
\text { Olive oil milling wastewater } \\
X_{\text {polyphenols }}=46-48 \%, X_{\mathrm{TOC}}: 18-22 \%\end{array}$ & [69] \\
\hline $\mathrm{Cu} / \mathrm{Al}-\mathrm{PILC}$ & $\begin{array}{l}\text { Tyrosol, major compound of the } \\
\text { polyphenolic fraction present in olive oil } \\
\text { mill wastewaters }\end{array}$ & $\begin{array}{l}T=25-80^{\circ} \mathrm{C} \\
X_{\text {Tyrosol }}=100 \%, X_{\mathrm{TOC}} \sim 80 \% \\
\text { Without significant leaching of copper ions }\end{array}$ & {$[70]$} \\
\hline$(\mathrm{Al}-\mathrm{Fe}) \mathrm{PILC}$ & $\begin{array}{l}\text { Polyphenols in olive mill wastewater } \\
\text { (OMW) }\end{array}$ & $\begin{array}{l}T=25-70^{\circ} \mathrm{C} \\
X_{\mathrm{COD}}=37-69 \%, X_{\text {polyphenols }}=54-100 \% \\
\text { Pretreated OMW reduced considerably the COD and } \\
\text { total phenolic contents }\end{array}$ & {$[71]$} \\
\hline Cu-PILC & $\begin{array}{l}\text { Real wastewaters from agro-food } \\
\text { production (Citrus juice production and } \\
\text { olive oil milling wastewater) }\end{array}$ & $\begin{array}{l}\text { Citrus juice production wastewater } \\
T=80^{\circ} \mathrm{C}, X_{\text {polyphenols }}=65-98 \% \\
X_{\mathrm{TOC}}=20-52 \% \\
\text { Cu leaching }=0.21-0.64 \mathrm{ppm} \\
\text { Olive oil milling wastewater } \\
T=80^{\circ} \mathrm{C}, X_{\text {polyphenols }}=18-39 \% \\
X_{\mathrm{TOC}}=7-30 \%\end{array}$ & {$[72]$} \\
\hline $\mathrm{Cu}-\mathrm{AZA}$ & $\begin{array}{l}\text { Wet hydrogen peroxide catalytic } \\
\text { oxidation of olive oil mill wastewaters } \\
\text { using a } \mathrm{Cu} \text {-pillared clay catalyst }\end{array}$ & $\begin{array}{l}T=80^{\circ} \mathrm{C} \\
X_{\text {polyphenols }}=45 \%, X_{\mathrm{TOC}}=13.5 \% \\
\text { No copper leaching during the oxidation reactions }\end{array}$ & {$[73]$} \\
\hline
\end{tabular}

COD in wastewater that is required by Colombian legislation can be achieved with the SMTA developed by Cenicafé [145].

3.1. WHPCO with AlFe-PILC as a Posttreatment System for Coffee Wet Processing Wastewater. The effluent from the anaerobic biological treatment of coffee wet processing wastewater (CWPW) developed in the National Coffee Research Center-Cenicafé still contains a nonbiodegradable compound that must be treated before it is discharged into a water source. It was found that chlorogenic acid, caffeic acid and tannins are toxic compounds because they inhibit the process of methanogenesis and limit the biodegradability of water during anaerobic digestion [138]. In the research group of "Solid State and Environmental Catalysis," the CWHPO using pillared clays with Al-Fe as catalysts was tested as a possible posttreatment system for coffee wet processing wastewater.

The physical chemical characterisation of the CWPW is detailed in Table 4. In general, with the use of the SMTA developed at Cenicafé, many of the contaminants present in wastewater as a result of the coffee wet processing were eliminated. However, the effluent of SMTA still retained an organic load that generated negative ecological impacts when deposited in the water bodies of the Colombian coffee zone, making posttreatment systems necessary.
A preliminary analysis of the phenolic compounds in CWPW was performed by HPLC-ESI-MS ${ }^{n}$ (highperformance liquid chromatography/electrospray ionization multiple mass spectrometry) by using a Shimadzu Liquid Chromatograph-Ion Trap-Time of Flight Mass Spectrometer (LCMS-IT-TOF, Kyoto, Japan). To conduct the analysis, $100 \mathrm{~mL}$ of WPCW were filtered through Millipore filters $(0.45 \mu \mathrm{m})$, and phenolic compounds were selectively obtained through successive extractions with $10 \mathrm{~mL}$ of ethyl acetate. Separation was performed in a Zorbax-SB C18 column $(250 \times 4.6 \mathrm{~mm}$ i.d., $5 \mu \mathrm{m}$, Phenomenex, USA). CWPW analysis (pos-biological treatment and precatalytic oxidation) using HPLC-ESI-MS ${ }^{\mathrm{n}}$ permitted a preliminary identification of compounds in the sample to compare with the values of $\mathrm{m} / \mathrm{z}$ (molecular ion and fragments) reported in the literature [146, 147]. The results showed that the CWPW contains mainly chlorogenic and hydroxycinnamic acids: 3-O-p-coumaroylquinic acid (3pCoQA), 4-O-p-coumaroylquinic acid (4-pCoQA), and 5$O$-p-coumaroylquinic acid (5-pCoQA), and caffeic and ferulic acids. These compounds have also been found in green coffee beans [146].

Considering the results of the analysis of phenolic compounds in CWPW, the catalytic activity of the pillared bentonite with $\mathrm{Al}-\mathrm{Fe}$ was evaluated in the oxidation reaction of three phenolic acids which were used as model molecules, 
TABle 4: Physicochemical parameters of coffee wet processing wastewater before and after biological treatment in SMTA.

\begin{tabular}{lcc}
\hline \multirow{2}{*}{ Parameters } & \multicolumn{2}{c}{ Water characteristics } \\
& Before $^{\mathrm{a}}$ & After $^{\mathrm{b}}$ \\
\hline $\mathrm{pH}$ & 4.2 & 6.5 \\
$\mathrm{BOD}_{5}\left(\mathrm{mg} \mathrm{O}_{2} / \mathrm{L}\right)$ & 2,990 & 284 \\
$\mathrm{COD}(\mathrm{mg} \mathrm{O} / \mathrm{L})$ & 6,580 & 551 \\
$\mathrm{COD} / \mathrm{BOD}$ & 2.2 & 1.9 \\
Total suspended solids $(\mathrm{mg} / \mathrm{L})$ & 435 & 904 \\
Acidity $(\mathrm{mg} / \mathrm{L})$ & 413 & 72 \\
Total phenols $(\mathrm{mg} / \mathrm{L})$ & $\mathrm{ND}$ & 165 \\
\hline
\end{tabular}

analysis conducted at Cenicafé.

${ }^{b}$ Analysis after biological treatment in hydrolytic acidogenic and methanogenic reactors (SMTA).

ND: Not determined because the sample contained a large amount of reducing sugars that generated interference and overestimated the total phenols content.

using a similar procedure as that reported in previous studies for phenol $[46,49,56,57]$. The phenolic acids used were chlorogenic (3-caffeoylquinic or 3-CQA), caffeic, and ferulic acids (Figure 1) at the following concentrations: $100 \mathrm{mg} / \mathrm{L}$ for 3-CQA and $40 \mathrm{mg} / \mathrm{L}$ for both caffeic and ferulic acids.

Traditionally, the tests with phenol as a model system are performed with $40 \mathrm{mg} / \mathrm{L}$ but, for 3-CQA, a higher concentration was used, given that 3-CQA is one of the most abundant compounds in the CWPW [138]. Monitoring of the phenolic acid conversion over time was conducted by high performance liquid chromatography (HPLC) using a Hitachi D-7000 (LaChrom) instrument equipped with a LiChrospher 60 Select B column, absorbance detector UV-vis L-7400, and, as a mobile phase, using a mixture of $\mathrm{H}_{2} \mathrm{O}, \mathrm{H}_{3} \mathrm{PO}_{4}$, and $\mathrm{CH}_{3} \mathrm{OH}$. The retention times for chlorogenic, caffeic, and ferulic acids were 9.3, 9.9 and $11.0 \mathrm{~min}$, respectively. Selectivity of the catalysts toward $\mathrm{CO}_{2}$ and $\mathrm{H}_{2} \mathrm{O}$ was evaluated using the analysis of total organic carbon (TOC) by an AnaTOC equipment.

Wet hydrogen peroxide catalytic oxidation tests of Al-FePILC with chlorogenic (3-CQA), caffeic, and ferulic acids showed a beneficial effect when incorporating $\mathrm{Fe}$ in the bentonite, both with respect to the phenolic acids conversion (Figure 2) and total organic carbon, TOC (Figure 3). The conversion of phenolic compounds using the catalyst $\mathrm{Al}-\mathrm{Fe}-$ PILC was higher for the chlorogenic acid (91\%), followed by caffeic acid (87\%) and ferulic acid (78\%) after $4 \mathrm{~h}$. Although a complete oxidation of these acids was not achieved, conversions higher than $78 \%$ are considered to be very good considering the complex structure of these compounds and the fact that the reaction was performed at $25^{\circ} \mathrm{C}$. Selectivity of the Al-Fe-PILC towards $\mathrm{CO}_{2}$ and $\mathrm{H}_{2} \mathrm{O}$ was higher for the chlorogenic acid (49\%), followed by the caffeic acid (37\%) and ferulic acid (34\%). These results are associated with differences in chemical structure. It was also found that the reactivity of phenolic compounds can be drastically affected by the electronic nature of substituents and by their positions in the aromatic ring $[148,149]$.

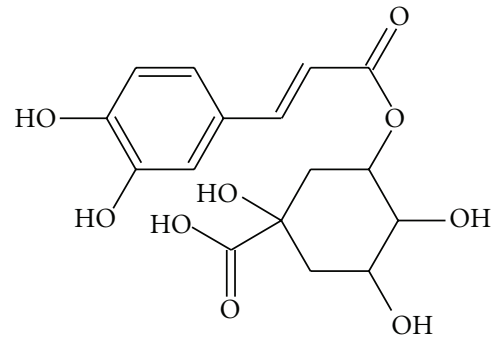

Chlorogenic acid (3-CQA)

3-(3, 4-dihydroxycinnamoyl)quinic acid

(a)

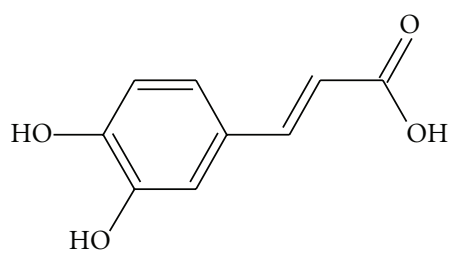

Caffeic acid

3, 4-dihydroxy-cinnamic acid

(b)

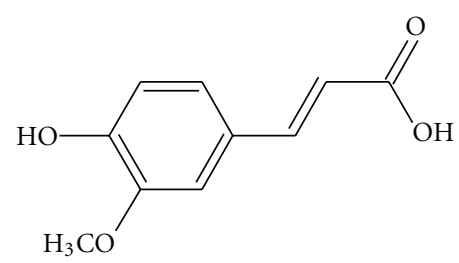

Ferulic acid

3-methoxy-4-hydroxycinnamic acid

(c)

Figure 1: Structure of phenolic acids.

The high conversion of chlorogenic acid can be explained by the presence of two electron-donating groups (as caffeic acid) and by three additional hydroxyl groups in the ester moiety. An example of the relationship between the chemical structure and its reactivity with hydroxyl radical would be the wet hydrogen peroxide photo-oxidation of p-coumaric, vanillic, ferulic, and caffeic acids when catalysed by (Al-Fe)PILC, in which the degradation of phenolic compounds was $28 \%, 50 \%, 58 \%$, and $86 \%$, respectively [148]. Because the hydroxyl radicals generated by the catalytic decomposition of $\mathrm{H}_{2} \mathrm{O}_{2}$ are both reactive and nonselective, the attack position in the aromatic ring can be located anywhere on the ring [150]. Therefore, the catalytic degradability of some phenolic compounds has been correlated by the Hammett constant $(\sigma)$, explaining the effect that different substituents have on the electronic character of a given aromatic system (electronwithdrawing or electron-donating groups) $[148,150]$. 


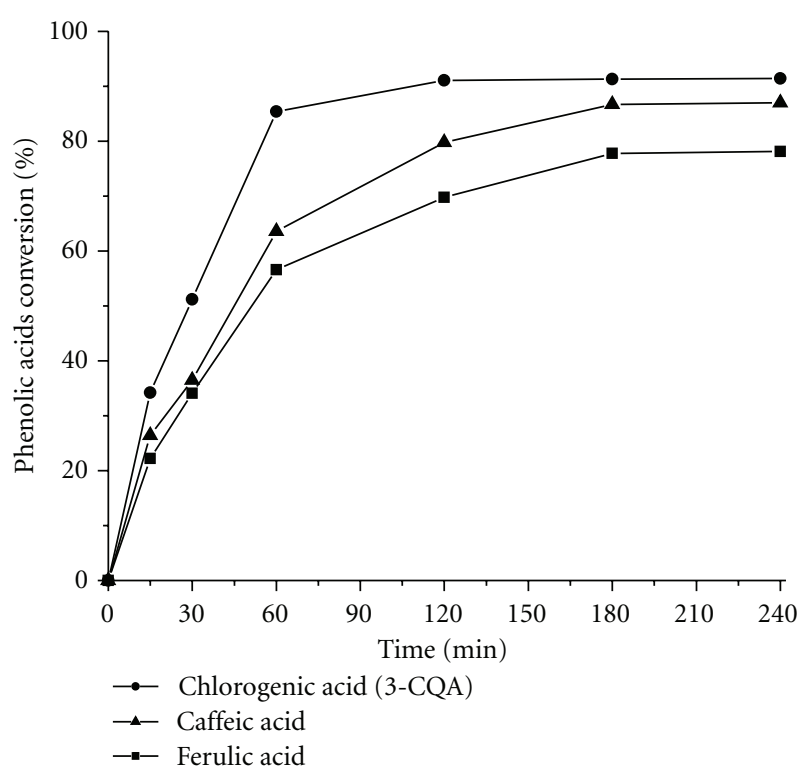

Figure 2: Phenolic acids conversion with AlFe-PILC.

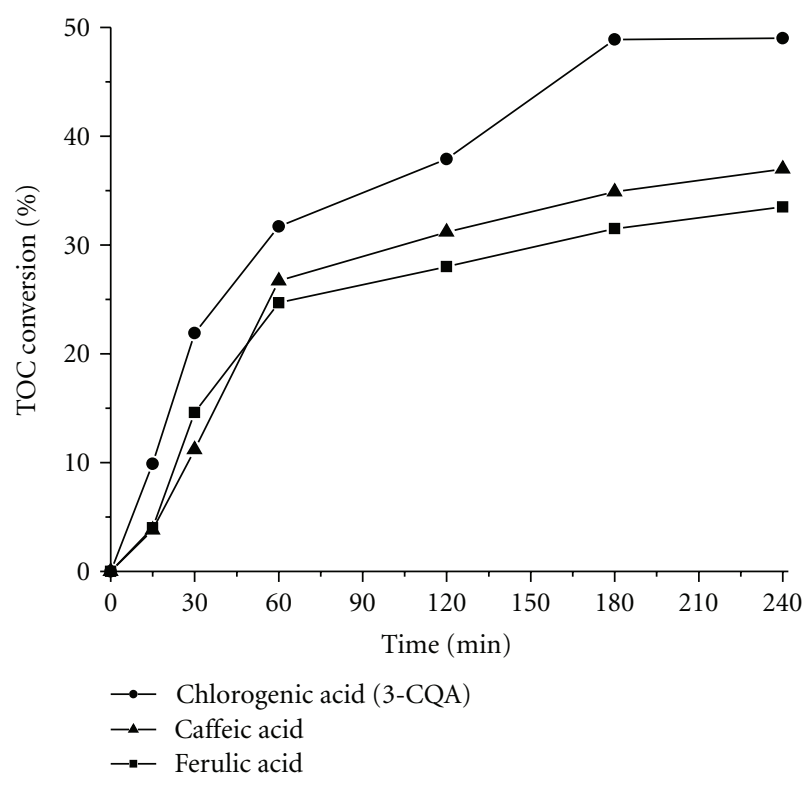

Figure 3: Total organic carbon (TOC) conversion with AlFe-PILC.

The reaction scheme for evaluating the catalytic activity of AlFe-PILC in the oxidation of the CWPW was described in Figure 4. For testing, the semibatch reactor thermostated at $25^{\circ} \mathrm{C}$ was loaded with $100 \mathrm{~mL}$ of coffee wastewater, $0.5 \mathrm{~g}$ of the catalyst, $0.1 \mathrm{M}$ hydrogen peroxide solution $(10 \mathrm{~mL}$, $2 \mathrm{~mL} / \mathrm{h})$, bubbling air at a constant flow $(2 \mathrm{~L} / \mathrm{h})$, and brought to a $\mathrm{pH}$ of 3.7 with $0.1 \mathrm{M} \mathrm{NaOH}$ or $\mathrm{HCl}$. The total phenol conversion in CWPW was performed using the FolinCiocalteu colorimetric method $[151,152]$. Selectivity of the catalysts toward $\mathrm{CO}_{2}$ and $\mathrm{H}_{2} \mathrm{O}$ or grade of mineralization was evaluated using the analysis of total organic carbon (TOC) with an AnaTOC equipment.

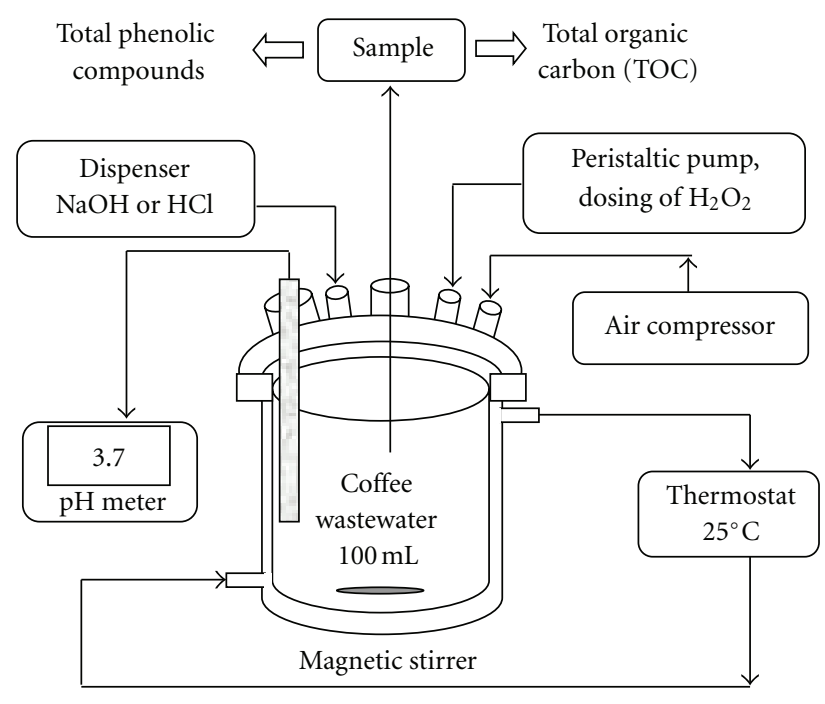

FIGURE 4: Diagram of the reaction system.

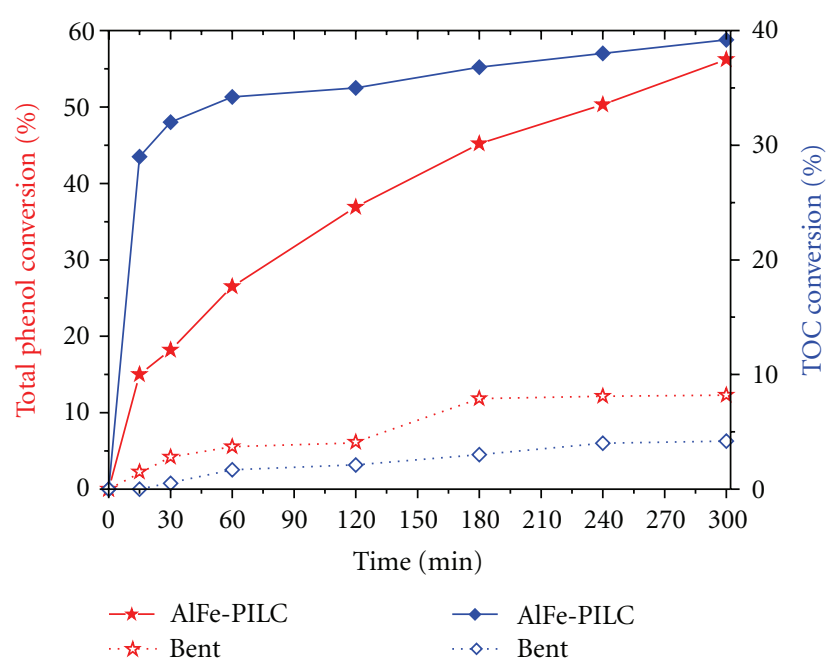

Figure 5: Catalytic oxidation of coffee wastewater with AlFe-PILC (continuous line) and Bent (dotted line). Total phenols conversion (star) and TOC conversion (diamond).

The AlFe-PILC achieved a high conversion rate of total phenolic compounds (56\%) and mineralization towards $\mathrm{CO}_{2}$ and $\mathrm{H}_{2} \mathrm{O}(40 \%)$ after $5 \mathrm{~h}$ reaction time (Figure 5). The starting bentonite (Bent) used as a reaction target achieved a conversion rate of phenolic compounds of $8 \%$ and selectivity to $\mathrm{CO}_{2}$ and $\mathrm{H}_{2} \mathrm{O}$ of $4 \%$, values attributed to the activity of iron in the starting clay $\left(8.2 \% \mathrm{Fe}_{2} \mathrm{O}_{3}\right)$. The chemical oxygen demand (COD) of coffee processing wastewater after wet hydrogen peroxide catalytic oxidation was reduced in $60 \%$. In terms of stability of the active phase, an average concentration of leached iron was $<0.22 \mathrm{ppm}$.

The combination of the two treatment methods, biological (developed by Cenicafé) and catalytic oxidation with AlFe-PILC, achieved a $96.7 \%$ reduction of COD in CWPW. These results are higher than those obtained when 
coffee processing wastewater was treated by coagulationflocculation in combination with advanced oxidation processes $\left(\mathrm{UV} / \mathrm{H}_{2} \mathrm{O}_{2} / \mathrm{O}_{3}\right)$, where a $\mathrm{COD}$ reduction of $87 \%$ was achieved [153]. Therefore, the WHPCO using AlFe-PILC catalysts is a viable alternative for the posttreatment of coffee processing wastewater.

\section{Conclusions}

The pillared clays have received considerable attention in the last decade as catalysts for wet hydrogen peroxide oxidation of phenolic compounds because of their high activity (conversion of phenolic compound and degree of mineralization) and environmental compatibility (low cost, easy recovery of the catalyst, are reusable catalysts, oxidation that can be carried out at room temperature and atmospheric pressure, and that they show high stability of the active phase in the reaction medium). With the developments in the synthesis of pillared clays, it has been possible to reduce the water volume and synthesis times, and technical requirements for these materials can be useful at industrial level.

Given the excellent properties of pillared clays in the WHPCO for phenol and other model molecules, as well as real wastewater treatment, this advanced oxidation process can be integrated with biological process, as a pre- or posttreatment, depending on the physicochemical characteristics of the wastewater.

The high conversion of phenolic compounds, the selectivity to $\mathrm{CO}_{2}$ and $\mathrm{H}_{2} \mathrm{O}$, and stability of the active phase in the pillared bentonite with Al-Fe in the WHPCO of coffee wastewater show the potentiality of this catalyst for posttreatment for this type of effluent. The combination of the two treatment methods, biological and catalytic oxidation with AlFe-PILC, achieved a $96.7 \%$ reduction of chemical oxygen demand in coffee wet processing wastewater.

\section{Acknowledgments}

The authors are grateful for the financial support provided by CSIC-COLCIENCIAS and DIB of Universidad Nacional de Colombia, Bogotá, for the development of several research projects conducted over the past 10 years. The authors also appreciate the cooperation received from the National Coffee Research Center-Cenicafé.

\section{References}

[1] R. J. Bigda, "Consider Fenton chemistry for waste-water treatment," Chemical Engineering Progress, vol. 91, no. 12, pp. 62-66, 1995.

[2] H. J. H. Fenton, "LXXIII.—oxidation of tartaric acid in presence of iron," Journal of the Chemical Society, Transactions, vol. 65, pp. 899-910, 1894.

[3] C. Walling, "Fenton's reagent revisited," Accounts of Chemical Research, vol. 8, no. 4, pp. 125-131, 1975.

[4] S. S. Lin and M. D. Gurol, "Catalytic decomposition of hydrogen peroxide on iron oxide: kinetics, mechanism, and implications," Environmental Science and Technology, vol. 32, no. 10, pp. 1417-1423, 1998.

[5] J. Beltran De Heredia, J. Torregrosa, J. R. Dominguez, and J. A. Peres, "Kinetic model for phenolic compound oxidation by Fenton's reagent," Chemosphere, vol. 45, no. 1, pp. 85-90, 2001.

[6] A. Safarzadeh-Amiri, J. R. Bolton, and S. R. Cater, "The use of iron in advanced oxidation processes," Journal of Advanced Oxidation Technologies, vol. 1, no. 1, pp. 18-26, 1996.

[7] G. Zelmanov and R. Semiat, "Phenol oxidation kinetics in water solution using iron(3)-oxide-based nano-catalysts," Water Research, vol. 42, no. 14, pp. 3848-3856, 2008.

[8] F. Haber and J. Weiss, "The catalytic decomposition of hydrogen peroxide by iron salts," Proceedings of the Royal Society of London A, vol. 147, no. 861, pp. 332-351, 1934.

[9] C. Walling, G. M. El-Taliawi, and R. A. Johnson, "Fenton's reagent. IV. Structure and reactivity relations in the reactions of hydroxyl radicals and the redox reactions of radicals," Journal of the American Chemical Society, vol. 96, no. 1, pp. 133-139, 1974.

[10] E. Chamarro, A. Marco, and S. Esplugas, "Use of Fenton reagent to improve organic chemical biodegradability," Water Research, vol. 35, no. 4, pp. 1047-1051, 2001.

[11] C. K. Duesterberg and T. D. Waite, "Process optimization of fenton oxidation using kinetic modeling," Environmental Science and Technology, vol. 40, no. 13, pp. 4189-4195, 2006.

[12] W. P. Ting, M. C. Lu, and Y. H. Huang, "The reactor design and comparison of Fenton, electro-Fenton and photoelectroFenton processes for mineralization of benzene sulfonic acid (BSA)," Journal of Hazardous Materials, vol. 156, no. 1-3, pp. 421-427, 2008.

[13] A. Babuponnusami and K. Muthukumar, "Advanced oxidation of phenol: a comparison between Fenton, electroFenton, sono-electro-Fenton and photo-electro-Fenton processes," Chemical Engineering Journal, vol. 183, pp. 1-9, 2012.

[14] H. Kušić, N. Koprivanac, A. L. Božić, and I. Selanec, "Photoassisted Fenton type processes for the degradation of phenol: a kinetic study," Journal of Hazardous Materials, vol. 136, no. 3, pp. 632-644, 2006.

[15] N. Kang, D. S. Lee, and J. Yoon, "Kinetic modeling of Fenton oxidation of phenol and monochlorophenols," Chemosphere, vol. 47, no. 9, pp. 915-924, 2002.

[16] S. Chou, Y. H. Huang, S. N. Lee, G. H. Huang, and C. Huang, "Treatment of high strength hexamine-containing wastewater by Electro-Fenton method," Water Research, vol. 33, no. 3, pp. 751-759, 1999.

[17] D. F. Bishop, G. Stern, M. Fleischman, and L. S. Marshall, "Hydrogen peroxide catalytic oxidation of refractory organics in municipal waste waters," IandEC Process Design and Development, vol. 7, no. 1, pp. 110-117, 1968.

[18] E. S. Henle and S. Linn, "Formation, prevention, and repair of DNA damage by iron/hydrogen peroxide," Journal of Biological Chemistry, vol. 272, no. 31, pp. 19095-19098, 1997.

[19] E. Neyens and J. Baeyens, "A review of classic Fenton's peroxidation as an advanced oxidation technique," Journal of Hazardous Materials, vol. 98, no. 1-3, pp. 33-50, 2003.

[20] K. H. Kim, J. R. Kim, and S. K. Ihm, "Wet oxidation of phenol over transition metal oxide catalysts supported on $\mathrm{Ce}_{0.65} \mathrm{Zr}_{0.35} \mathrm{O}_{2}$ prepared by continuous hydrothermal synthesis in supercritical water," Journal of Hazardous Materials, vol. 167, no. 1-3, pp. 1158-1162, 2009.

[21] K. H. Kim and S. K. Ihm, "Heterogeneous catalytic wet air oxidation of refractory organic pollutants in industrial 
wastewaters: a review," Journal of Hazardous Materials, vol. 186, no. 1, pp. 16-34, 2011.

[22] F. Arena, C. Italiano, A. Raneri, and C. Saja, "Mechanistic and kinetic insights into the wet air oxidation of phenol with oxygen (CWAO) by homogeneous and heterogeneous transition-metal catalysts," Applied Catalysis B, vol. 99, no. 12, pp. 321-328, 2010.

[23] X. Domènech, W. F. Jardim, and M. I. Litter, "Procesos avanzados de oxidación para la eliminación de contaminantes," in Eliminación de contaminantes por fotocatálisis heterogénea, M. Blesa, Ed., pp. 3-26, CYTED, La Plata, Argentina, 2001.

[24] A. N. Soon and B. H. Hameed, "Heterogeneous catalytic treatment of synthetic dyes in aqueous media using Fenton and photo-assisted Fenton process," Desalination, vol. 269, no. 1-3, pp. 1-16, 2011.

[25] S. Moreno, N. Sanabria, and R. Molina, "Chapter 4. Recent tendences in the synthesis of pillared clays for phenol oxidation," in Focus on Water Resource Research, E. Heikkine, Ed., pp. 185-209, Nova Science Publischer, New York, NY, USA, 2008.

[26] T. S. R. Prasada Rao and G. Murali Dhar, Recent Advanced in Basic and Applied Aspects of Industrial Catalysis, Elsevier Science B. V., Amsterdam, The Netherlands, 1998.

[27] N. R. Sanabria, R. Molina, and S. Moreno, "Raschig rings based on pillared clays: efficient reusable catalysts for oxidation of phenol," Journal of Advanced Oxidation Technologies, vol. 15, no. 1, pp. 117-124, 2012.

[28] J. K. Kim, F. Martinez, and I. S. Metcalfe, "The beneficial role of use of ultrasound in heterogeneous Fenton-like system over supported copper catalysts for degradation of p-chlorophenol," Catalysis Today, vol. 124, no. 3-4, pp. 224231, 2007.

[29] H. Hassan and B. H. Hameed, "Fe-clay as effective heterogeneous Fenton catalyst for the decolorization of Reactive Blue 4," Chemical Engineering Journal, vol. 171, no. 3, pp. 912-918, 2011.

[30] T. D. Nguyen, N. H. Phan, M. H. Do, and K. T. Ngo, "Magnetic $\mathrm{Fe}_{2} \mathrm{MO}_{4}$ (M:Fe, Mn) activated carbons: fabrication, characterization and heterogeneous Fenton oxidation of methyl orange," Journal of Hazardous Materials, vol. 185, no. 2-3, pp. 653-661, 2011.

[31] S. H. Tian, Y. T. Tu, D. S. Chen, X. Chen, and Y. Xiong, "Degradation of Acid Orange II at neutral $\mathrm{pH}$ using $\mathrm{Fe}_{2}\left(\mathrm{MoO}_{4}\right)_{3}$ as a heterogeneous Fenton-like catalyst," Chemical Engineering Journal, vol. 169, no. 1-3, pp. 31-37, 2011.

[32] M. Dükkanci, G. Gündüz, S. Yilmaz, and R. V. Prihod'ko, "Heterogeneous Fenton-like degradation of Rhodamine 6G in water using CuFeZSM-5 zeolite catalyst prepared by hydrothermal synthesis," Journal of Hazardous Materials, vol. 181, no. 1-3, pp. 343-350, 2010.

[33] R. Idel-aouad, M. Valiente, A. Yaacoubi, B. Tanouti, and M. López-Mesas, "Rapid decolourization and mineralization of the azo dye C.I. Acid Red 14 by heterogeneous Fenton reaction," Journal of Hazardous Materials, vol. 186, no. 1, pp. 745-750, 2011.

[34] H. Kušić, N. Koprivanac, and I. Selanec, "Fe-exchanged zeolite as the effective heterogeneous Fenton-type catalyst for the organic pollutant minimization: UV irradiation assistance," Chemosphere, vol. 65, no. 1, pp. 65-73, 2006.

[35] E. V. Kuznetsova, E. N. Savinov, L. A. Vostrikova, and V. N. Parmon, "Heterogeneous catalysis in the Fenton-type system FeZSM-5/ $\mathrm{H}_{2} \mathrm{O}_{2}$," Applied Catalysis B, vol. 51, no. 3, pp. 165 $170,2004$.
[36] G. B. Ortiz de la Plata, O. M. Alfano, and A. E. Cassano, "Decomposition of 2-chlorophenol employing goethite as Fenton catalyst II: reaction kinetics of the heterogeneous Fenton and photo-Fenton mechanisms," Applied Catalysis B, vol. 95, no. 1-2, pp. 14-25, 2010.

[37] R. C. C. Costa, F. C. C. Moura, J. D. Ardisson, J. D. Fabris, and R. M. Lago, "Highly active heterogeneous Fentonlike systems based on $\mathrm{Fe}^{0} / \mathrm{Fe}_{3} \mathrm{O}_{4}$ composites prepared by controlled reduction of iron oxides," Applied Catalysis B, vol. 83, no. 1-2, pp. 131-139, 2008.

[38] F. C. C. Moura, M. H. Araujo, R. C. C. Costa et al., "Efficient use of $\mathrm{Fe}$ metal as an electron transfer agent in a heterogeneous Fenton system based on $\mathrm{Fe}^{0} / \mathrm{Fe}_{3} \mathrm{O}_{4}$ composites," Chemosphere, vol. 60, no. 8, pp. 1118-1123, 2005.

[39] S.-P. Sun and A. T. Lemley, "P-Nitrophenol degradation by a heterogeneous Fenton-like reaction on nano-magnetite: process optimization, kinetics, and degradation pathways," Journal of Molecular Catalysis A, vol. 349, no. 1-2, pp. 71-79, 2011.

[40] F. Martínez, G. Calleja, J. A. Melero, and R. Molina, "Heterogeneous photo-Fenton degradation of phenolic aqueous solutions over iron-containing SBA-15 catalyst," Applied Catalysis B, vol. 60, no. 3-4, pp. 181-190, 2005.

[41] R. Molina, F. Martínez, J. A. Melero, D. H. Bremner, and A. G. Chakinala, "Mineralization of phenol by a heterogeneous ultrasound/Fe-SBA- $15 / \mathrm{H}_{2} \mathrm{O}_{2}$ process: multivariate study by factorial design of experiments," Applied Catalysis B, vol. 66, no. 3-4, pp. 198-207, 2006.

[42] P. Shukla, S. Wang, H. Sun, H. M. Ang, and M. Tadé, "Adsorption and heterogeneous advanced oxidation of phenolic contaminants using Fe loaded mesoporous SBA-15 and $\mathrm{H}_{2} \mathrm{O}_{2}$," Chemical Engineering Journal, vol. 164, no. 1, pp. 255260, 2010.

[43] L. A. Galeano, M. Á. Vicente, and A. Gil, "Treatment of municipal leachate of landfill by fenton-like heterogeneous catalytic wet peroxide oxidation using an Al/Fe-pillared montmorillonite as active catalyst," Chemical Engineering Journal, vol. 178, pp. 146-153, 2011.

[44] M. Luo, D. Bowden, and P. Brimblecombe, "Catalytic property of Fe-Al pillared clay for Fenton oxidation of phenol by $\mathrm{H}_{2} \mathrm{O}_{2}$," Applied Catalysis B, vol. 85, no. 3-4, pp. 201-206, 2009.

[45] C. B. Molina, J. A. Casas, J. A. Zazo, and J. J. Rodríguez, “A comparison of Al-Fe and Zr-Fe pillared clays for catalytic wet peroxide oxidation," Chemical Engineering Journal, vol. 118, no. 1-2, pp. 29-35, 2006.

[46] J. G. Carriazo, E. Guelou, J. Barrault, J. M. Tatibouët, and S. Moreno, "Catalytic wet peroxide oxidation of phenol over Al$\mathrm{Cu}$ or Al-Fe modified clays," Applied Clay Science, vol. 22, no. 6, pp. 303-308, 2003.

[47] J. Carriazo, E. Guélou, J. Barrault, J. M. Tatibouët, R. Molina, and S. Moreno, "Catalytic wet peroxide oxidation of phenol by pillared clays containing Al-Ce-Fe," Water Research, vol. 39, no. 16, pp. 3891-3899, 2005.

[48] J. Carriazo, E. Guélou, J. Barrault, J. M. Tatibouët, R. Molina, and S. Moreno, "Synthesis of pillared clays containing Al, $\mathrm{Al}-\mathrm{Fe}$ or Al-Ce-Fe from a bentonite: characterization and catalytic activity," Catalysis Today, vol. 107-108, pp. 126-132, 2005.

[49] J. G. Carriazo, M. A. Centeno, J. A. Odriozola, S. Moreno, and R. Molina, "Effect of Fe and Ce on Al-pillared bentonite and their performance in catalytic oxidation reactions," Applied Catalysis A, vol. 317, no. 1, pp. 120-128, 2007. 
[50] J. G. Carriazo, R. Molina, and S. Moreno, "A study on Al and $\mathrm{Al}-\mathrm{Ce}-\mathrm{Fe}$ pillaring species and their catalytic potential as they are supported on a bentonite," Applied Catalysis A, vol. 334, no. 1-2, pp. 168-172, 2008.

[51] A. Pérez, M. A. Centeno, J. A. Odriozola, R. Molina, and S. Moreno, "The effect of ultrasound in the synthesis of clays used as catalysts in oxidation reactions," Catalysis Today, vol. 133-135, no. 1-4, pp. 526-529, 2008.

[52] N. Sanabria, A. Álvarez, R. Molina, and S. Moreno, "Synthesis of pillared bentonite starting from the Al-Fe polymeric precursor in solid state, and its catalytic evaluation in the phenol oxidation reaction," Catalysis Today, vol. 133-135, no. 1-4, pp. 530-533, 2008.

[53] A. Olaya, S. Moreno, and R. Molina, "Synthesis of pillared clays with $\mathrm{Al}_{13}-\mathrm{Fe}$ and $\mathrm{Al}_{13}-\mathrm{Fe}$-Ce polymers in solid state assisted by microwave and ultrasound: characterization and catalytic activity," Applied Catalysis A, vol. 370, no. 1-2, pp. $7-15,2009$.

[54] A. Olaya, G. Blanco, S. Bernal, S. Moreno, and R. Molina, "Synthesis of pillared clays with Al-Fe and Al-Fe-Ce starting from concentrated suspensions of clay using microwaves or ultrasound, and their catalytic activity in the phenol oxidation reaction," Applied Catalysis B, vol. 93, no. 1-2, pp. $56-65,2009$

[55] A. Olaya, S. Moreno, and R. Molina, "Synthesis of pillared clays with aluminum by means of concentrated suspensions and microwave radiation," Catalysis Communications, vol. 10, no. 5, pp. 697-701, 2009.

[56] N. R. Sanabria, M. A. Centeno, R. Molina, and S. Moreno, "Pillared clays with $\mathrm{Al}-\mathrm{Fe}$ and $\mathrm{Al}-\mathrm{Ce}-\mathrm{Fe}$ in concentrated medium: synthesis and catalytic activity," Applied Catalysis A, vol. 356, no. 2, pp. 243-249, 2009.

[57] N. R. Sanabria, R. Molina, and S. Moreno, "Effect of ultrasound on the structural and textural properties of AlFe pillared clays in a concentrated medium," Catalysis Letters, vol. 130, no. 3-4, pp. 664-671, 2009.

[58] J. Barrault, C. Bouchoule, K. Echachoui, N. Frini-Srasra, M. Trabelsi, and F. Bergaya, "Catalytic wet peroxide oxidation (CWPO) of phenol over mixed (Al-Cu)-pillared clays," Applied Catalysis B, vol. 15, no. 3-4, pp. 269-274, 1998.

[59] C. Catrinescu, C. Teodosiu, M. Macoveanu, J. MieheBrendlé, and R. Le Dred, "Catalytic wet peroxide oxidation of phenol over Fe-exchanged pillared beidellite," Water Research, vol. 37, no. 5, pp. 1154-1160, 2003.

[60] J. Barrault, M. Abdellaoui, C. Bouchoule et al., "Catalytic wet peroxide oxidation over mixed (Al-Fe) pillared clays," Applied Catalysis B, vol. 27, no. 4, pp. L225-L230, 2000.

[61] N. R. Sanabria, P. Ávila, M. Yates, S. B. Rasmussen, R. Molina, and S. Moreno, "Mechanical and textural properties of extruded materials manufactured with $\mathrm{AlFe}$ and AlCeFe pillared bentonites," Applied Clay Science, vol. 47, no. 3-4, pp. 283-289, 2010.

[62] J. Barrault, J. M. Tatibouët, and N. Papayannakos, "Catalytic wet peroxide oxidation of phenol over pillared clays containing iron or copper species," Comptes Rendus de l'Academie des Sciences, vol. 3, no. 10, pp. 777-783, 2000.

[63] E. Guélou, J. Barrault, J. Fournier, and J. M. Tatibouët, "Active iron species in the catalytic wet peroxide oxidation of phenol over pillared clays containing iron," Applied Catalysis B, vol. 44, no. 1, pp. 1-8, 2003.

[64] M. N. Timofeeva, S. T. Khankhasaeva, S. V. Badmaeva et al., "Synthesis, characterization and catalytic application for wet oxidation of phenol of iron-containing clays," Applied Catalysis B, vol. 59, no. 3-4, pp. 243-248, 2005.
[65] E. E. Kiss, M. M. Lazic, and G. C. Boskovic, "AlFe-pillared clay catalyst for phenol oxidation in aqueous solution," Reaction Kinetics and Catalysis Letters, vol. 83, no. 2, pp. 221227, 2004.

[66] J. Guo and M. Al-Dahhan, "Catalytic wet oxidation of phenol by hydrogen peroxide over pillared clay catalyst," Industrial and Engineering Chemistry Research, vol. 42, no. 12, pp. 24502460, 2003.

[67] A. N. Nikolopoulos, O. Igglessi-Markopoulou, and N. Papayannakos, "Ultrasound assisted catalytic wet peroxide oxidation of phenol: kinetics and intraparticle diffusion effects," Ultrasonics Sonochemistry, vol. 13, no. 1, pp. 92-97, 2006.

[68] J. M. Tatibouët, E. Guélou, and J. Fournier, "Catalytic oxidation of phenol by hydrogen peroxide over a pillared clay containing iron. Active species and $\mathrm{pH}$ effect," Topics in Catalysis, vol. 33, no. 1-4, pp. 225-232, 2005.

[69] S. Caudo, G. Centi, C. Genovese, and S. Perathoner, "Copperand iron-pillared clay catalysts for the WHPCO of model and real wastewater streams from olive oil milling production," Applied Catalysis B, vol. 70, no. 1-4, pp. 437-446, 2007.

[70] R. B. Achma, A. Ghorbel, A. Dafinov, and F. Medina, "Copper-supported pillared clay catalysts for the wet hydrogen peroxide catalytic oxidation of model pollutant tyrosol," Applied Catalysis A, vol. 349, no. 1-2, pp. 20-28, 2008.

[71] S. Azabou, W. Najjar, M. Bouaziz, A. Ghorbel, and S. Sayadi, "A compact process for the treatment of olive mill wastewater by combining wet hydrogen peroxide catalytic oxidation and biological techniques," Journal of Hazardous Materials, vol. 183, no. 1-3, pp. 62-69, 2010.

[72] S. Caudo, C. Genovese, S. Perathoner, and G. Centi, "Copperpillared clays (Cu-PILC) for agro-food wastewater purification with $\mathrm{H}_{2} \mathrm{O}_{2}$," Microporous and Mesoporous Materials, vol. 107, no. 1-2, pp. 46-57, 2008.

[73] G. Giordano, S. Perathoner, G. Centi et al., "Wet hydrogen peroxide catalytic oxidation of olive oil mill wastewaters using $\mathrm{Cu}$-zeolite and Cu-pillared clay catalysts," Catalysis Today, vol. 124, no. 3-4, pp. 240-246, 2007.

[74] M. Pimentel, N. Oturan, M. Dezotti, and M. A. Oturan, "Phenol degradation by advanced electrochemical oxidation process electro-Fenton using a carbon felt cathode," Applied Catalysis B, vol. 83, no. 1-2, pp. 140-149, 2008.

[75] G. Busca, S. Berardinelli, C. Resini, and L. Arrighi, "Technologies for the removal of phenol from fluid streams: a short review of recent developments," Journal of Hazardous Materials, vol. 160, no. 2-3, pp. 265-288, 2008.

[76] H. Ma, X. Zhang, Q. Ma, and B. Wang, "Electrochemical catalytic treatment of phenol wastewater," Journal of Hazardous Materials, vol. 165, no. 1-3, pp. 475-480, 2009.

[77] H. H. P. Fang, D. W. Liang, T. Zhang, and Y. Liu, "Anaerobic treatment of phenol in wastewater under thermophilic condition," Water Research, vol. 40, no. 3, pp. 427-434, 2006.

[78] W. Kujawski, A. Warszawski, W. Ratajczak, T. Porębski, W. Capała, and I. Ostrowska, "Removal of phenol from wastewater by different separation techniques," Desalination, vol. 163, no. 1-3, pp. 287-296, 2004.

[79] A. Santos, P. Yustos, S. Gomis, G. Ruiz, and F. Garcia-Ochoa, "Reaction network and kinetic modeling of wet oxidation of phenol catalyzed by activated carbon," Chemical Engineering Science, vol. 61, no. 8, pp. 2457-2467, 2006.

[80] M. Pérez, F. Torrades, J. A. García-Hortal, X. Domènech, and J. Peral, "Removal of organic contaminants in paper 
pulp treatment effluents under Fenton and photo-Fenton conditions," Applied Catalysis B, vol. 36, no. 1, pp. 63-74, 2002.

[81] M. G. Joshi and R. L. Shambaugh, "The kinetics of ozonephenol reaction in aqueous solutions," Water Research, vol. 16, no. 6, pp. 933-938, 1982.

[82] A. M. Amat, A. Arques, F. López, and M. A. Miranda, "Solar photo-catalysis to remove paper mill wastewater pollutants," Solar Energy, vol. 79, no. 4, pp. 393-401, 2005.

[83] S. Perathoner and G. Centi, "Wet hydrogen peroxide catalytic oxidation (WHPCO) of organic waste in agro-food and industrial streams," Topics in Catalysis, vol. 33, pp. 207-224, 2005.

[84] I. U. Castro, D. C. Sherrington, A. Fortuny et al., "Synthesis of polymer-supported copper complexes and their evaluation in catalytic phenol oxidation," Catalysis Today, vol. 157, no. 1-4, pp. 66-70, 2010.

[85] N. Crowther and F. Larachi, "Iron-containing silicalites for phenol catalytic wet peroxidation," Applied Catalysis B, vol. 46, no. 2, pp. 293-305, 2003.

[86] N. Inchaurrondo, J. Cechini, J. Font, and P. Haure, "Strategies for enhanced CWPO of phenol solutions," Applied Catalysis B, vol. 111-112, pp. 641-648, 2012.

[87] P. Massa, A. Dafinov, F. M. Cabello, and R. Fenoglio, "Catalytic wet peroxide oxidation of phenolic solutions over $\mathrm{Fe}_{2} \mathrm{O}_{3} / \mathrm{CeO}_{2}$ and $\mathrm{WO}_{3} / \mathrm{CeO}_{2}$ catalyst systems," Catalysis Communications, vol. 9, no. 7, pp. 1533-1538, 2008.

[88] P. Massa, F. Ivorra, P. Haure, and R. Fenoglio, "Catalytic wet peroxide oxidation of phenol solutions over $\mathrm{CuO} / \mathrm{CeO}_{2}$ systems," Journal of Hazardous Materials, vol. 190, no. 1-3, pp. 1068-1073, 2011.

[89] G. Calleja, J. A. Melero, F. Martínez, and R. Molina, "Activity and resistance of iron-containing amorphous, zeolitic and mesostructured materials for wet peroxide oxidation of phenol," Water Research, vol. 39, no. 9, pp. 1741-1750, 2005.

[90] A. Quintanilla, A. F. Fraile, J. A. Casas, and J. J. Rodríguez, "Phenol oxidation by a sequential CWPO-CWAO treatment with a Fe/AC catalyst," Journal of Hazardous Materials, vol. 146, no. 3, pp. 582-588, 2007.

[91] A. Rey, J. Carbajo, C. Adán et al., "Improved mineralization by combined advanced oxidation processes," Chemical Engineering Journal, vol. 174, no. 1, pp. 134-142, 2011.

[92] A. Rey, M. Faraldos, J. A. Casas, J. A. Zazo, A. Bahamonde, and J. J. Rodríguez, "Catalytic wet peroxide oxidation of phenol over Fe/AC catalysts: influence of iron precursor and activated carbon surface," Applied Catalysis B, vol. 86, no. 1-2, pp. 69-77, 2009.

[93] J. A. Zazo, J. A. Casas, A. F. Mohedano, and J. J. Rodríguez, "Catalytic wet peroxide oxidation of phenol with a Fe/active carbon catalyst," Applied Catalysis B, vol. 65, no. 3-4, pp. 261268, 2006.

[94] K. M. Valkaj, A. Katovic, and S. Zrnčević, "Investigation of the catalytic wet peroxide oxidation of phenol over different types of Cu/ZSM-5 catalyst," Journal of Hazardous Materials, vol. 144, no. 3, pp. 663-667, 2007.

[95] X. Zhong, J. Barbier, D. Duprez, H. Zhang, and S. Royer, "Modulating the copper oxide morphology and accessibility by using micro-/mesoporous SBA-15 structures as host support: effect on the activity for the CWPO of phenol reaction," Applied Catalysis B, vol. 121-122, pp. 123-134, 2012.

[96] S. Zhou, Z. Qian, T. Sun, J. Xu, and C. Xia, "Catalytic wet peroxide oxidation of phenol over $\mathrm{Cu}-\mathrm{Ni}-\mathrm{Al}$ hydrotalcite," Applied Clay Science, vol. 53, no. 4, pp. 627-633, 2011.
[97] E. V. Parkhomchuk, M. P. Vanina, and S. Preis, "The activation of heterogeneous Fenton-type catalyst Fe-MFI," Catalysis Communications, vol. 9, no. 3, pp. 381-385, 2008.

[98] D. Tabet, M. Saidi, M. Houari, P. Pichat, and H. Khalaf, "Fe-pillared clay as a Fenton-type heterogeneous catalyst for cinnamic acid degradation," Journal of Environmental Management, vol. 80, no. 4, pp. 342-346, 2006.

[99] F. Bergaya, A. Aouad, and T. Mandalia, "Chapter 7.5 Pillared clays and clay minerals. Developments in clay science," in Handbook of Clay Science, pp. 393-421, Elsevier, Amsterdam, The Netherlands, 2006.

[100] J. Barrault, C. Bouchoule, J. M. Tatibouët et al., "Catalytic wet peroxide oxidation over mixed (Al-Fe) pillared clays," in Studies in Surface Science and Catalysis, A. Corma, F. V. Melo, S. Mendioroz, and J. L. Fierro, Eds., pp. 749-754, Elsevier, Amsterdam, The Netherlands, 2000.

[101] R. M. Barrer and D. M. Macleod, "Activation of montmorillonite by ion exchange and sorption complexes of tetra-alkyl ammonium montmorillonites," Transactions of the Faraday Society, vol. 51, pp. 1290-1300, 1955.

[102] R. A. Schoonheydt, T. Pinnavaia, G. Lagaly, and N. Gangas, "Pillared clays and pillared layered solids," Pure and Applied Chemistry, vol. 71, no. 12, pp. 2368-2371, 1999.

[103] M. L. Occelli, J. A. Bertrand, S. A. C. Gould, and J. M. Dominguez, "Physicochemical characterization of a Texas montmorillonite pillared with polyoxocations of aluminum Part I: the microporous structure," Microporous and Mesoporous Materials, vol. 34, no. 2, pp. 195-206, 2000.

[104] J. P. Olivier and M. L. Occelli, "Surface area and microporosity of pillared rectorite catalysts from a hybrid density functional theory method," Microporous and Mesoporous Materials, vol. 57, no. 3, pp. 291-296, 2003.

[105] J. L. Valverde, A. Romero, R. Romero, P. B. García, M. L. Sánchez, and I. Asencio, "Preparation and characterization of Fe-PILCS. Influence of the synthesis parameters," Clays and Clay Minerals, vol. 53, no. 6, pp. 613-621, 2005.

[106] W. Diano, R. Rubino, and M. Sergio, "Al-pillared montmorillonite: preparation from concentrated slurries of homoionic Ca clay, characterization and thermal stability," Microporous Materials, vol. 2, no. 3, pp. 179-184, 1994.

[107] G. Fetter, G. Heredia, L. A. Velázquez, A. M. Maubert, and P. Bosch, "Synthesis of aluminum-pillared montmorillonites using highly concentrated clay suspensions," Applied Catalysis A, vol. 162, no. 1-2, pp. 41-45, 1997.

[108] R. Molina, A. Vieira-Coelho, and G. Poncelet, "Hydroxy-Al pillaring of concentrated clay suspensions," Clays and Clay Minerals, vol. 40, no. 4, pp. 480-482, 1992.

[109] P. Salerno and S. Mendioroz, "Preparation of Al-pillared montmorillonite from concentrated dispersions," Applied Clay Science, vol. 22, no. 3, pp. 115-123, 2002.

[110] A. Sánchez and M. Montes, "Influence of the preparation parameters (particle size and aluminium concentration) on the textural properties of Al-pillared clays for a scale-up process," Microporous and Mesoporous Materials, vol. 21, no. 1-3, pp. 117-125, 1998.

[111] L. Storaro, M. Lenarda, M. Perissinotto, V. Lucchini, and R. Ganzerla, "Hydroxy-Al pillaring of concentrated suspensions of smectite clays," Microporous and Mesoporous Materials, vol. 20, no. 4-6, pp. 317-331, 1998.

[112] S. P. Katdare, V. Ramaswamy, and A. V. Ramaswamy, "Ultrasonication: a competitive method of intercalation for the preparation of alumina pillared montmorillonite catalyst," Catalysis Today, vol. 49, no. 1-3, pp. 313-320, 1999. 
[113] S. P. Katdare, V. Ramaswamy, and A. V. Ramaswamy, "Factors affecting the preparation of alumina pillared montmorillonite employing ultrasonics," Microporous and Mesoporous Materials, vol. 37, no. 3, pp. 329-336, 2000.

[114] V. Singh, V. Sapehiyia, and G. L. Kad, "Ultrasound and microwave activated preparation of $\mathrm{ZrO}_{2}$-pillared clay composite: catalytic activity for selective, solventless acylation of 1,n-diols," Journal of Molecular Catalysis A, vol. 210, no. 1-2, pp. 119-124, 2004.

[115] G. Fetter, V. Hernández, V. Rodríguez, M. A. Valenzuela, V. H. Lara, and P. Bosch, "Effect of microwave irradiation time on the synthesis of zirconia-pillared clays," Materials Letters, vol. 57, no. 5-6, pp. 1220-1223, 2003.

[116] A. M. De Andrés, J. Merino, J. C. Galván, and E. Ruiz-Hitzky, "Synthesis of pillared clays assisted by microwaves," Materials Research Bulletin, vol. 34, no. 4, pp. 641-651, 1999.

[117] A. Aouad, T. Mandalia, and F. Bergaya, "A novel method of Al-pillared montmorillonite preparation for potential industrial up-scaling," Applied Clay Science, vol. 28, no. 1-4, pp. 175-182, 2005.

[118] C. B. Molina, J. A. Casas, A. H. Pizarro, and J. J. Rodriguez, "Pillared Clays as green chemistry catalysts: application to wastewater treatment," in Clay: Types, Properties and Uses, J. P. Humphrey and D. E. Boyd, Eds., pp. 435-474, Nova Science, New York, NY, USA, 2011.

[119] S. Moreno-Guáqueta, R. Molina-Gallego, N. R. SanabriaGonzález, and A. J. Olaya-Avendaño, "Procedimiento para la modificación de arcilla con el sistema mixto Al-Fe o AlCe-Fe," Patente IPC C 01 B 033/020, Superintendencia de Industria y Comercio, Colombia, 2007.

[120] F. Mohino, A. B. Martin, P. Salerno, A. Bahamonde, and S. Mendioroz, "High surface area monoliths based on pillared clay materials as carriers for catalytic processes," Applied Clay Science, vol. 29, no. 2, pp. 125-136, 2005.

[121] L. F. Liotta, M. Gruttadauria, G. Di Carlo, G. Perrini, and V. Librando, "Heterogeneous catalytic degradation of phenolic substrates: catalysts activity," Journal of Hazardous Materials, vol. 162, no. 2-3, pp. 588-606, 2009.

[122] C. Catrinescu, D. Arsene, and C. Teodosiu, "Catalytic wet hydrogen peroxide oxidation of para-chlorophenol over $\mathrm{Al} / \mathrm{Fe}$ pillared clays (AlFePILCs) prepared from different host clays," Applied Catalysis B, vol. 101, no. 3-4, pp. 451-460, 2011.

[123] L. Chirchi and A. Ghorbel, "Use of various Fe-modified montmorillonite samples for 4-nitrophenol degradation by $\mathrm{H}_{2} \mathrm{O}_{2}$," Applied Clay Science, vol. 21, no. 5-6, pp. 271-276, 2002.

[124] M. J. Hernando, C. Pesquera, C. Blanco, and F. González, "Synthesis, characterization, and catalytic properties of pillared montmorillonite with aluminum/cerium polyoxycations," Chemistry of Materials, vol. 13, no. 6, pp. 2154-2159, 2001.

[125] M. J. Hernando, C. Pesquera, C. Blanco, and F. González, "Increase in thermal stability of the texture in montmorillonites pillared with aluminum/cerium polyoxocations," Langmuir, vol. 18, no. 14, pp. 5633-5636, 2002.

[126] G. Fetter, P. Salas, L. A. Velazquez, and P. Bosch, "Ce-Alpillared clays: synthesis, characterization, and catalytic performance," Industrial and Engineering Chemistry Research, vol. 39, no. 6, pp. 1944-1949, 2000.

[127] S. K. Kim and S. K. Ihm, "Effects of Ce addition and Pt precursor on the activity of $\mathrm{Pt} / \mathrm{Al}_{2} \mathrm{O}_{3}$ catalysts for wet oxidation of phenol," Industrial and Engineering Chemistry Research, vol. 41, no. 8, pp. 1967-1972, 2002.

[128] K. Al-Malah, M. O. J. Azzam, and N. I. Abu-Lail, “Olive mills effluent (OME) wastewater post-treatment using activated clay," Separation and Purification Technology, vol. 20, no. 23, pp. 225-234, 2000.

[129] J. Herney-Ramirez, M. A. Vicente, and L. M. Madeira, "Heterogeneous photo-Fenton oxidation with pillared claybased catalysts for wastewater treatment: a review," Applied Catalysis B, vol. 98, no. 1-2, pp. 10-26, 2010.

[130] C. Pulgarin, M. Invernizzi, S. Parra, V. Sarria, R. Polania, and P. Péringer, "Strategy for the coupling of photochemical and biological flow reactors useful in mineralization of biorecalcitrant industrial pollutants," Catalysis Today, vol. 54, no. 2-3, pp. 341-352, 1999.

[131] R. Ben Achma, A. Ghorbel, S. Sayadi, A. Dafinov, and F. Medina, "A novel method of copper-exchanged aluminumpillared clay preparation for olive oil mill wastewater treatment," Journal of Physics and Chemistry of Solids, vol. 69, no. 5-6, pp. 1116-1120, 2008.

[132] R. L. Lucier, The International Political Economy of Coffee: From Juan Valdez to Yank's Diner, Praeger Publishers, New York, NY, USA, 1988.

[133] FNC, "Federación Nacional de Cafeteros de Colombia. Colombia es cafe," 2012, http://www.federaciondecafeteros .org/algrano-fnc-es/index.php/comments/colombia_es_cafe.

[134] H. N. Chanakya and A. A. P. De Alwis, "Environmental issues and management in primary coffee processing," Process Safety and Environmental Protection, vol. 82, no. 4 B, pp. 291300, 2004.

[135] J. N. Wintgens and C. H. J. Brando, "Harvesting and green coffee processing," in Coffee: Growing, Processing, Sustainable Production: A Guidebook for Growers, Processors, Traders, and Researchers, J. N. Wintgens, Ed., pp. 610-723, Wiley-VCH, Weinheim, Germany, 2009.

[136] G. S. Duarte, A. A. Pereira, and A. Farah, "Chlorogenic acids and other relevant compounds in Brazilian coffees processed by semi-dry and wet post-harvesting methods," Food Chemistry, vol. 118, no. 3, pp. 851-855, 2010.

[137] N. Rodríguez-Valencia and D. A. Zambrano-Franco, "Los subproductos del café: fuente de energía renovable," Avances Técnicos Cenicafé, no. 393, pp. 1-8, 2010.

[138] J. Field, "Aguas residuales del café," in Arranque y operación de sistemas de flujo ascedente con mato de lodos-UASB, pp. H1H11, Universidad del Valle-CVC, Santiago de Calí, Colombia, 1987.

[139] N. Rodríguez-Valencia, Estudio de un biosistema integrado para el postratamiento de las aguas residuales del café utilizando macrófitas acuáticas [Ph.D. thesis], Universidad Politécnica de Valencia, Valencia, Spain, 2009.

[140] D. A. Zambrano-Franco, N. Rodríguez-Valencia, U. LópezPosada, P. A. Orozco-Restrepo, and A. J. Zambrano-Giraldo, "Tratamiento anaerobio de las aguas mieles del café," Boletin Técnico Cenicafé, vol. 29, pp. 1-28, 2006.

[141] V. Matuk-Velasco, N. Rodríguez-Valencia, and G. I. PuertaQuintero, "El impacto biológico de los efluentes del beneficio húmedo de café," Cenicafé, vol. 48, no. 4, pp. 234-252, 1997.

[142] R. Bello-Mendoza and M. F. Castillo-Rivera, "Start-up of an anaerobic hybrid (UASB/filter) reactor treating wastewater from a coffee processing plant," Anaerobe, vol. 4, no. 5, pp. 219-225, 1998.

[143] F. R. L. Fia, A. T. Matos, A. C. Borges, R. Fia, and P. R. Cecon, "Treatment of wastewater from coffee bean processing in anaerobic fixed bed reactors with different support materials: 
performance and kinetic modeling," Journal of Environmental Management, vol. 108, pp. 14-21, 2012.

[144] M. Selvamurugan, P. Doraisamy, and M. Maheswari, "An integrated treatment system for coffee processing wastewater using anaerobic and aerobic process," Ecological Engineering, vol. 36, no. 12, pp. 1686-1690, 2010.

[145] "Decreto 1594 del 26 de junio de 1984, por el cual se reglamenta parcialmente el Título 1 de la Ley 9 de 1979, así como el Capítulo II del Título VI -Parte III- Libro II y el Título III de la Parte 111 -Libro I-del DecretoLey 2811 de 1974 en cuanto a usos del agua y residuos líquidos," Ministerio de Agricultura de Colombia, Bogotá DC, Colombia, 1984.

[146] M. N. Clifford, S. Knight, B. Surucu, and N. Kuhnert, "Characterization by LC-MS" of four new classes of chlorogenic acids in green coffee beans: dimethoxycinnamoylquinic acids, diferuloylquinic acids, caffeoyl-dimethoxycinnamoylquinic acids, and feruloyl- dimethoxycinnamoylquinic acids," Journal of Agricultural and Food Chemistry, vol. 54, no. 6, pp. 1957-1969, 2006.

[147] R. Jaiswal, M. A. Patras, P. J. Eravuchira, and N. Kuhnert, "Profile and characterization of the chlorogenic acids in green Robusta coffee beans by LC-MS ${ }^{\mathrm{n}}$ : identification of seven new classes of compounds," Journal of Agricultural and Food Chemistry, vol. 58, no. 15, pp. 8722-8737, 2010.

[148] S. Azabou, W. Najjar, A. Gargoubi, A. Ghorbel, and S. Sayadi, "Catalytic wet peroxide photo-oxidation of phenolic olive oil mill wastewater contaminants. Part II. Degradation and detoxification of low-molecular mass phenolic compounds in model and real effluent," Applied Catalysis B, vol. 77, no. 1-2, pp. 166-174, 2007.

[149] S. Parra, J. Olivero, L. Pacheco, and C. Pulgarin, "Structural properties and photoreactivity relationships of substituted phenols in $\mathrm{TiO}_{2}$ suspensions," Applied Catalysis B, vol. 43, no. 3, pp. 293-301, 2003.

[150] J. A. Peres, J. R. Domínguez, and J. Beltran-Heredia, "Reaction of phenolic acids with Fenton-generated hydroxyl radicals: hammett correlation," Desalination, vol. 252, no. 13, pp. 167-171, 2010.

[151] V. L. Singleton and J. A. Rossi, "Colorimetry of total phenolics with phosphomolybdicphosphotungstic acid reagents," American Journal of Enology and Viticulture, vol. 16, no. 3, pp. 144-158, 1965.

[152] V. L. Singleton, R. Orthofer, and R. M. Lamuela-Raventós, "Analysis of total phenols and other oxidation substrates and antioxidants by means of folin-ciocalteu reagent," Methods in Enzymology, vol. 299, pp. 152-178, 1998.

[153] T. Zayas Pérez, G. Geissler, and F. Hernandez, "Chemical oxygen demand reduction in coffee wastewater through chemical flocculation and advanced oxidation processes," Journal of Environmental Sciences, vol. 19, no. 3, pp. 300-305, 2007. 


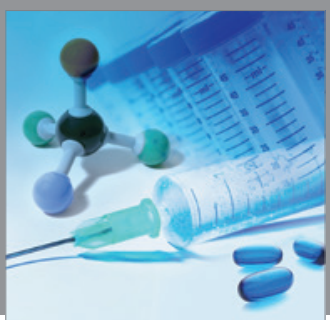

International Journal of

Medicinal Chemistry

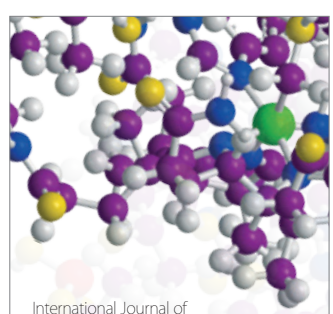

Carbohydrate Chemistry

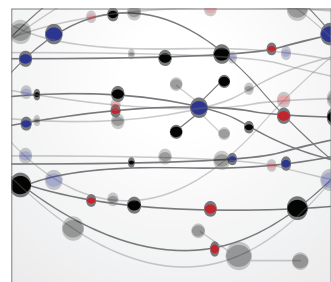

The Scientific World Journal
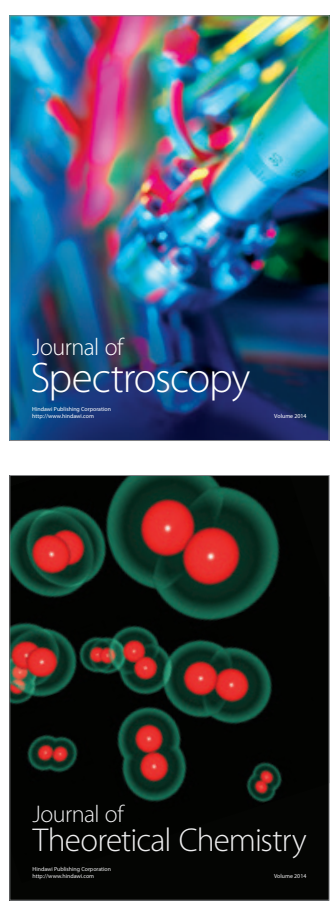
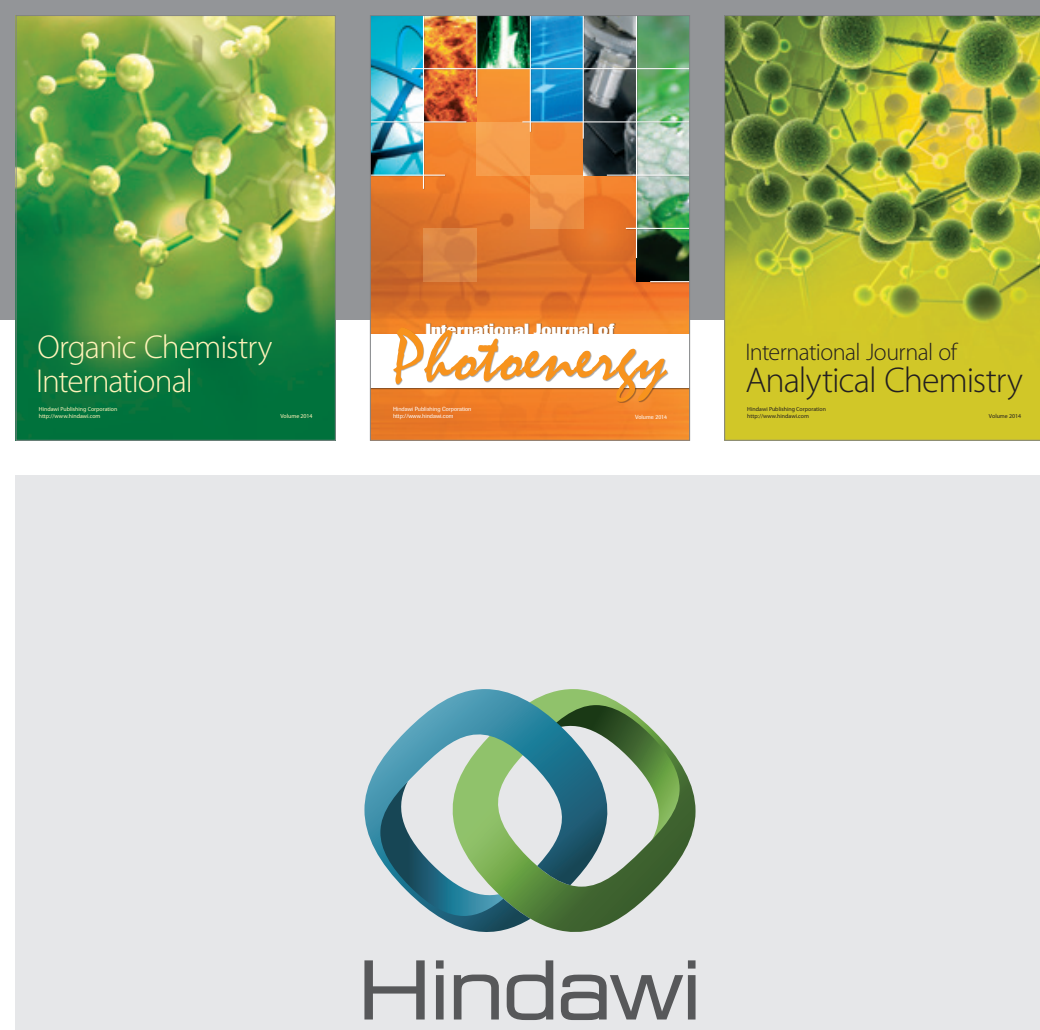

Submit your manuscripts at

http://www.hindawi.com
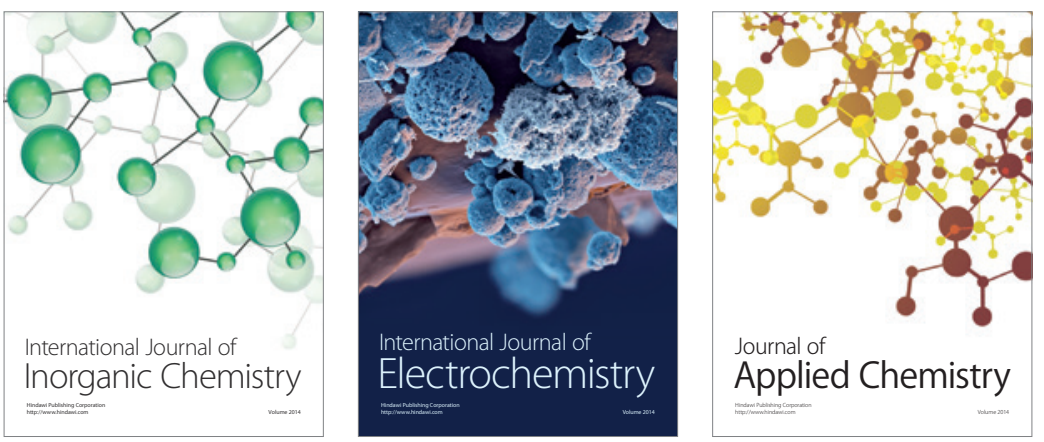

Journal of

Applied Chemistry
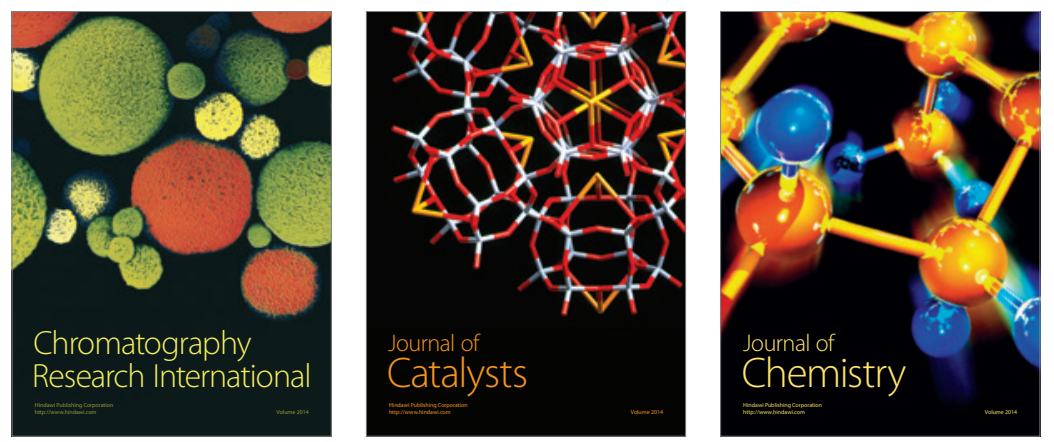
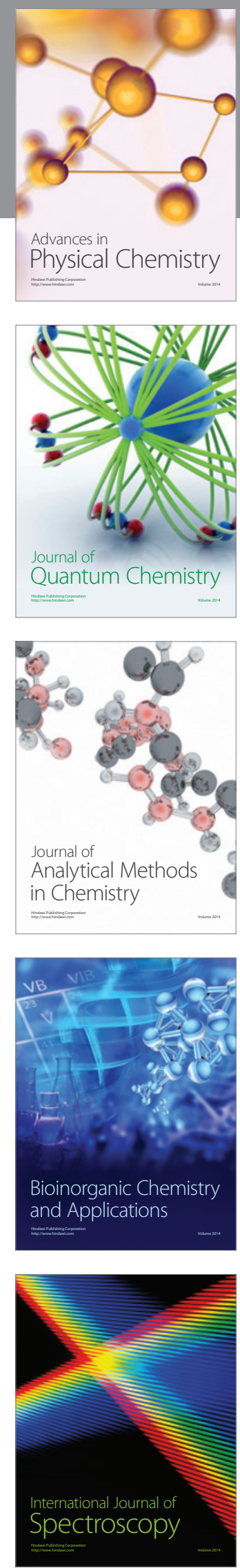